\title{
Sectorrapportage Hoger Economisch Onderwijs
}

Citation for published version (APA):

Allen, J. P., van Thor, J. A. F., \& Verhagen, A. M. C. (2013). Sectorrapportage Hoger Economisch

Onderwijs. ROA. ROA Reports No. 002 https://doi.org/10.26481/umarep.2013002

Document status and date:

Published: 01/01/2013

DOI:

10.26481/umarep.2013002

Document Version:

Publisher's PDF, also known as Version of record

\section{Please check the document version of this publication:}

- A submitted manuscript is the version of the article upon submission and before peer-review. There can be important differences between the submitted version and the official published version of record.

People interested in the research are advised to contact the author for the final version of the publication, or visit the DOI to the publisher's website.

- The final author version and the galley proof are versions of the publication after peer review.

- The final published version features the final layout of the paper including the volume, issue and page numbers.

Link to publication

\footnotetext{
General rights rights.

- You may freely distribute the URL identifying the publication in the public portal. please follow below link for the End User Agreement:

www.umlib.nl/taverne-license

Take down policy

If you believe that this document breaches copyright please contact us at:

repository@maastrichtuniversity.nl

providing details and we will investigate your claim.
}

Copyright and moral rights for the publications made accessible in the public portal are retained by the authors and/or other copyright owners and it is a condition of accessing publications that users recognise and abide by the legal requirements associated with these

- Users may download and print one copy of any publication from the public portal for the purpose of private study or research.

- You may not further distribute the material or use it for any profit-making activity or commercial gain

If the publication is distributed under the terms of Article $25 \mathrm{fa}$ of the Dutch Copyright Act, indicated by the "Taverne" license above, 


\section{Sectorrapportage Hoger Economisch Onderwijs}

Jim Allen

Jesper van Thor

Annelore Verhagen

ROA-R-2013/2 


\section{Colofon}

(C) Researchcentrum voor Onderwijs en Arbeidsmarkt (ROA). Niets uit deze uitgave mag op enige manier worden verveelvoudigd zonder voorafgaande schriftelijke toestemming van de directeur van het ROA.

\section{Researchcentrum voor Onderwijs en Arbeidsmarkt}

School of Business and Economics

Maastricht University

\section{Vormgeving}

ROA secretariaat, Maastricht

\section{Verkoop}

Researchcentrum voor Onderwijs en Arbeidsmarkt email: secretary-roa-sbe@maastrichtuniversity.nl website: www.roa.nl

ISBN: 978-90-532I-507-4

februari 2013 


\section{Inhoud}

1 Inleiding 1

2 De arbeidsmarkt voor afgestudeerden van het HEO 7

3 Arbeidsmarktdynamiek $\quad 21$

3.1 Indicator toekomstig arbeidsmarktperspectief (ITA) 21

$\begin{array}{ll}3.2 \text { Uitwijkmogelijkheden } & 23\end{array}$

$\begin{array}{ll}3.3 \text { Substitutiemogelijkheden } & 24\end{array}$

4 Vereiste competenties voor afgestudeerden van het HEO 27

4.1 Trends en mogelijke implicaties voor vereiste competenties 27

$\begin{array}{ll}4.2 \text { Vereist niveau competenties } & 30\end{array}$

$\begin{array}{ll}4.3 \text { Competentietekorten } & 33\end{array}$

$\begin{array}{lll}5 & \text { Conclusie } & 37\end{array}$

$\begin{array}{ll}\text { Literatuur } & 39\end{array}$

Bijlage: Kernindicatoren voor HEO Bachelor-opleidingen $\quad 41$ 



\section{Inleiding}

De HBO-Monitor vierde in 2010 haar 20-jarige bestaan. In de eerste twintig jaar van de $\mathrm{HBO}-$ Monitor is op verschillende manieren gerapporteerd over de aansluiting tussen het $\mathrm{HBO}$ en de arbeidsmarkt, over de vraag wat de $\mathrm{HBO}$-studenten tijdens hun studie hebben geleerd en over de vraag hoe zij de gevolgde opleiding beoordelen. Hierbij is vooral gericht gerapporteerd op landelijk niveau en op het niveau van de onderwijsinstelling. De tussenliggende laag, de afzonderlijke sectoren, is daarbij (met uitzondering van het eerste jaar van de HBO-Monitor) zelden als insteek gebruikt. Afgezien van de sector Kunst, wordt voor de resterende zes sectoren: Economie, Gezondheidszorg, Landbouw, Pedagogisch, Sociaal-agogisch en Techniek in het kader van het 20-jarige bestaan dan ook een rapport geschreven met de betreffende sector als centraal ankerpunt. Vanuit dit perspectief is de voorliggende rapportage specifiek gericht op de HBO-sector Hoger Economisch Onderwijs (HEO). Hierbij staan de implicaties van recente alsook toekomstige arbeidsmarktontwikkelingen in de sector op de gevraagde competenties van afgestudeerden centraal. Zo wordt achterhaald op welke competenties het onderwijsveld zich de komende jaren zou moeten richten om afgestudeerden optimaal voor te kunnen bereiden op hun beroepsloopbaan in de economische sector.

De context van deze rapportage wordt gevormd door de strategische agenda $\mathrm{HO}$ en het hoofdlijnenakkoord tussen de HBO-raad en het Ministerie van Onderwijs, Cultuur en Wetenschap (Ministerie van OC\&W, 20II). Hierin worden afspraken gemaakt over het met een zekere regelmaat uitvoeren van sectorale verkenningen. De huidige rapportage in het kader van het 20-jarige bestaan van de HBO-Monitor levert relevant materiaal voor die sectorale verkenningen.

\section{Leeswijzer}

Als uitgangspunt voor voorliggende sectorrapportage wordt in hoofdstuk I allereerst kort een algemeen beeld van deze sector geschetst. Vervolgens wordt in hoofdstuk 2 aan de hand van een breed scala aan indicatoren de arbeidsmarktsituatie voor recent afgestudeerden van het Hoger Economisch Onderwijs beschreven. Hierna wordt in hoofdstuk 3 stilgestaan bij de arbeidsmarktdynamiek van de economische sector. Dit wordt gedaan aan de hand van de verwachte arbeidsmarktperspectieven voor afgestudeerden van het HEO. Tevens komen hier de uitwijk- en substitutiemogelijkheden van HEO-afgestudeerden over de tijd aan bod. Zo wordt achterhaald of het beroe- 
pendomein voor deze jongeren breder of smaller wordt. Tot slot wordt in hoofdstuk 4 ingegaan op de competenties die recent afgestudeerden dienen te bezitten en worden in hoofdstuk 5 de belangrijkste conclusies op een rij gezet. In de bijlage worden de resultaten voor enkele kernindicatoren uitgesplitst naar HEO Bachelor-opleidingen.

\section{HEO cijfermatig in beeld}

Hoewel in 2010 het aantal instromers in het Hoger Economisch Onderwijs van alle sectoren binnen het hoger beroepsonderwijs (HBO) met 2,7\% het meest gedaald is ten opzichte van 2009, is dit nog altijd veruit de grootste sector. Bovendien groeide tot 2010 de instroom bij de economische $\mathrm{HBO}$-opleidingen ieder jaar zelfs met zo'n 2 tot $7 \%$. In 2010 kozen 40.300 bachelor-instromers voor een economische opleiding (HBO-raad, 20I2). Van het totaal aantal studenten dat in 2010 ingeschreven staat bij een $\mathrm{HBO}$-opleiding (4I7.000) volgt ruim 4 op de Io een economische opleiding (zo'n I67.000). Tabel I.I geeft voor 2010 een overzicht van de tien bachelor-opleidingen met het grootste aantal studenten binnen de economische sector. Deze bestond in 2010 in totaal uit zo'n I67.000 studenten. De opleiding commerciële economie is veruit het meest populair, maar ook voor communicatie, bedrijfseconomie, management, economie en recht, en rechten kiezen elk meer dan I0.000 studenten.

\section{Tabel 1.1}

De 10 grootste opleidingen binnen het Hoger Economisch Onderwijs in 2010

\begin{tabular}{|l|l|r|} 
& Opleiding: & Inschrijvingen \\
\hline 1 & commerciële economie & 21.057 \\
\hline 2 & communicatie & 12.138 \\
\hline 3 & bedrijfseconomie & 12.128 \\
\hline 4 & opleiding voor management, economie en recht & 11.291 \\
\hline 5 & hbo-rechten & 10.131 \\
\hline 6 & international business and management studies (economie) & 9.022 \\
\hline 7 & personeel en arbeid & 8.911 \\
\hline 8 & accountancy & 6.646 \\
\hline 9 & media en entertainment management & 5.584 \\
\hline 10 & small business en retail management & 5.328 \\
\hline & HEO totaal & 167.019 \\
\hline
\end{tabular}

Bron: HBO-raad (2012)/bewerking ROA

Een belangrijk actueel thema voor de economische opleidingen is de verbetering van het studiesucces (HBO-raad, 20IO). Dit geldt met name voor de hoofdfase en in mindere mate voor de propedeuse. Om het studiesucces te verbeteren is een speciale werkgroep in het leven geroepen die de problematiek omtrent het studiesucces in kaart heeft gebracht. Belangrijke uitkomsten zijn onder meer dat er bij de economische opleidingen meer lang-studeerders zijn, vrouwen het beter doen dan mannen, en vaker dan in andere sectoren de volgende twee redenen genoemd worden om te 
stoppen met de studie: onvoldoende motivatie en verkeerde studiekeuze. Daar staat tegenover dat de opleiding juist minder vaak als te zwaar wordt ervaren.

Maar wie kiezen nu precies voor deze opleidingen in de economische sector? Tabel I.2 bevat een aantal achtergrondkenmerken van de afgestudeerden van het Hoger Economisch Onderwijs. Ter vergelijking worden ook de cijfers voor het $\mathrm{HBO}$ als geheel gepresenteerd.

\section{Tabel 1.2}

Achtergrondkenmerken van recent afgestudeerden van het HEO, 2006-2010

\begin{tabular}{|l|r|r|}
\hline Vrouw (\%) & $\begin{array}{r}\text { HBO } \\
\text { economie }\end{array}$ & HBO totaal \\
\hline Leeftijd (gem.) & $51,0 \%$ & $55,9 \%$ \\
\hline Allochtoon (\%) & 24,9 & 25,2 \\
\hline westerse & & \\
\hline niet-westerse & $8,1 \%$ & $7,2 \%$ \\
\hline Hoogst voltooide vooropleiding (\%) & $8,9 \%$ & $6,2 \%$ \\
\hline HAVO & & \\
\hline VWO & $52,4 \%$ & $48,8 \%$ \\
\hline MBO & $17,7 \%$ & $16,7 \%$ \\
\hline HBO & $24,3 \%$ & $26,8 \%$ \\
\hline andere vooropleiding & $3,7 \%$ & $5,3 \%$ \\
\hline Vervolgopleiding gevolgd (\%) & $1,9 \%$ & $2,3 \%$ \\
\hline B & $24,0 \%$ & $22,1 \%$ \\
\hline
\end{tabular}

Bron: HBO-Monitor 2006-2010

In termen van geslacht, leeftijd, etniciteit en voor- en vervolgopleiding wijken HEO'ers niet veel af van het $\mathrm{HBO}$ als geheel. Het aandeel vrouwen en de gemiddelde leeftijd liggen iets onder het HBO-gemiddelde, het aandeel allochtonen - zowel westerse als niet-westerse - juist iets erboven. Daarnaast zijn afgestudeerden van het HEO iets vaker op basis van een vooropleiding op de middelbare school (HAVO of VWO) aan een HEO-opleiding begonnen en iets minder vaak op basis van een vooropleiding op $\mathrm{MBO}$ of $\mathrm{HBO}$ niveau. Ook zijn zij iets vaker na afronding van die opleiding doorgestroomd naar een vervolgopleiding.

Tabel I.3 geeft de tien populairste branches weer waar recent afgestudeerden van het HEO werkzaam zijn. De data zijn afkomstig van de HBO-Monitor. De cijfers hebben betrekking op de periode 2006-20Io en geven de branches weer waarin de grootste groepen voormalige HEO'ers actief zijn op het enquêtemoment, circa I,5 jaar na afstuderen. 
Tabel 1.3

Aandeel werkende recent afgestudeerden van het HEO per branche, 2006-2010 (\%)

\begin{tabular}{|c|c|c|c|}
\hline & Branche: & $\begin{array}{r}\text { HEO } \\
\%\end{array}$ & $\begin{array}{r}\text { HBO totaal } \\
\%\end{array}$ \\
\hline 1 & Rechtskundige dienstverlening, accountancy, belastingadvisering en administratie & 8,5 & 3,4 \\
\hline 2 & Arbeidsbemiddeling, uitzendbureaus en personeelsbeheer & 7,5 & 3,6 \\
\hline 3 & Openbaar bestuur, overheidsdiensten en verplichte sociale verzekeringen & 7,0 & 4,8 \\
\hline 4 & Financiële instellingen (geen verzekeringen en pensioenfondsen) & 6,7 & 2,8 \\
\hline 5 & Groothandel en handelsbemiddeling (niet in auto's en motorfietsen) & 6,5 & 3,7 \\
\hline 6 & Dienstverlenende activiteiten op het gebied van informatietechnologie & 4,9 & 4,8 \\
\hline 7 & Detailhandel (niet in auto's) & 4,6 & 2,5 \\
\hline 8 & $\begin{array}{l}\text { Holdings (geen financiële), concerndiensten binnen eigen concern en } \\
\text { managementadvisering }\end{array}$ & 3,6 & 2,0 \\
\hline 9 & Logiesverstrekking & 3,3 & 1,2 \\
\hline 10 & Onderwijs & 3,1 & 17,4 \\
\hline
\end{tabular}

Bron: HBO-Monitor 2006-2010

In de periode 2006-20I0 waren er in totaal bijna 6I.700 recent afgestudeerde HBO'ers met een economische opleiding die betaald werk verrichtten. Van deze groep was het grootste deel $(8,5 \%)$ werkzaam in de 'rechtskundige dienstverlening, accountancy, belastingadvisering en administratie'. Dit komt overeen met zo'n 5.I80 werkende personen. Eveneens een substantieel deel van de afgestudeerden van het HEO werkte de afgelopen jaren bij 'arbeidsbemiddelaars, uitzendbureaus en personeelsbeheerders' (7,5\%). Hieruit blijkt dat startende HEO-afgestudeerden voornamelijk kiezen voor een werkgever in de zakelijke dienstverlening. De top-3 wordt gecompleteerd door de branche 'openbaar bestuur, overheidsdiensten en verplichte sociale verzekeringen $(7,0 \%)$. Dat er toch nog relatief veel afgestudeerden van het Hoger Economisch Onderwijs in deze branche terechtkomen is op zich vrij opvallend te noemen, aangezien vaak gedacht wordt dat afgestudeerden doorgaans vooral voor de private sector kiezen. 6,7\% van de recent afgestudeerden van het Hoger Economisch Onderwijs werkt voor een financiële instelling (exclusief verzekeringen en pensioenfondsen) of werkt in de 'groothandel en handelsbemiddeling' (6,5\%).

Minder dan vijf procent van het totaal aantal afgestudeerden van het Hoger Economisch Onderwijs is werkzaam in de overige branches. Zoals verwacht is er dus sprake van grote diversiteit in de branches waar afgestudeerden van deze sector gaan werken. Naast de eerder genoemde branches kiezen HEO-afgestudeerden relatief vaak voor een baan bij een dienstverlener op het gebied van informatietechnologie, in de detailhandel (exclusief auto's), bij '(niet-financiële) holdings, concerndiensten binnen eigen concern en managementadvisering', in de logiesverstrekking of in het onderwijs. Hoewel in laatstgenoemde branche 'slechts' 3,I\% van het totaal aantal recent afgestudeerden van het $\mathrm{HEO}$ werkzaam is, gaat het in deze periode nog altijd om ruim I.900 recent afgestudeerden. 
Tevens is voor deze periode (2006-20I0) gekeken in welke branches afgestudeerden van het HEO de dominante groep zijn. Gemiddeld genomen heeft ruim een derde van het totaal aantal afgestudeerde HBO'ers een economische opleidingsachtergrond $(35,9 \%)$. Tabel I.4 geeft de branches weer met het hoogste aandeel afgestudeerden van het HEO. ${ }^{1}$

Tabel 1.4

Branches waar afgestudeerden van het HEO de dominante groep zijn onder HBO-afgestudeerden, 2006-2010 (\%)

\begin{tabular}{|l|l|r|}
\hline & Branche: & $\%$ HEO \\
\hline 1 & Logiesverstrekking & 95,3 \\
\hline 2 & Reisbemiddeling, reisorganisatie, toeristische informatie en reserveringsbureaus & 93,3 \\
\hline 3 & Rechtskundige dienstverlening, accountancy, belastingadvisering en administratie & 90,6 \\
\hline 4 & Overige financiële dienstverlening & 86,7 \\
\hline 5 & Financiële instellingen (geen verzekeringen en pensioenfondsen) & 85,8 \\
\hline 6 & Verzekeringen en pensioenfondsen (geen verplichte sociale verzekeringen) & 84,7 \\
\hline 7 & Uitgeverijen & 79,0 \\
\hline 8 & Verhuur en lease van auto's, consumentenartikelen, machines en overige roerende goederen & 78,2 \\
\hline 9 & Arbeidsbemiddeling, uitzendbureaus en personeelsbeheer & 75,5 \\
\hline 10 & Verzorgen en uitzenden van radio- en televisieprogramma's & 75,2 \\
\hline
\end{tabular}

Bron: HBO-Monitor 2006-2010

Opmerking: Alleen branches waarbinnen ten minste $100 \mathrm{HEO}$-afgestudeerden werkzaam zijn worden weergegeven.

Afgestudeerden van het HEO zijn in een groot aantal branches de dominante groep. In vrijwel elke branche worden dan ook arbeidskrachten met een economische opleidingsachtergrond gevraagd. Dit in tegenstelling tot $\mathrm{HBO}$-opleidingen in bijvoorbeeld de gezondheidszorg.

Uit de tabel blijkt dat afgestudeerden van het HEO vooral dominant zijn in de zakelijke dienstverlening. In de logiesverstrekking werken relatief gezien de meeste HEO-afgestudeerden. In deze branche heeft ruim 95\% van de recent afgestudeerde werkenden een economische opleidingsachtergrond. De tweede plaats wordt ingenomen door de 'reisbemiddeling, reisorganisatie, toeristische informatie en reserveringsbureaus'. In deze branche hebben ook meer dan 9 op de Io recent afgestudeerde HBO'ers een economische opleiding gevolgd. De top-3 van branches waar recent afgestudeerde HEO'ers dominant zijn wordt vervolledigd door de 'rechtskundige dienstverlening, accountancy, belastingadvisering en administratie’ (90,6\%).

Andere branches die in belangrijke mate gedomineerd worden door afgestudeerden van het HEO zijn in aflopende volgorde van grootte de 'overige financiële dienstverlening', 'financiële instellingen' (exclusief verzekeringen en pensioenfondsen), 'verzekeringen en pensioenfondsen' (exclusief verplichte sociale verzekeringen), 'uitgeverijen',

I. Er zijn branches met een nog hoger aandeel afgestudeerden van het HEO, maar het gaat dan om relatief kleine branches. Derhalve worden branches met minder dan Ioo HEO-afgestudeerden hier buiten beschouwing gelaten. 
'verhuur en lease van auto's, consumentenartikelen, machines en overige roerende goederen', 'arbeidsbemiddeling, uitzendbureaus en personeelsbeheer' en 'verzorgen en uitzenden van radio- en televisieprogramma's'. In laatstgenoemde branche heeft nog altijd driekwart van alle werkende recent afgestudeerde HBO'ers een diploma in de sector economie.

Tabel I.5 geeft de belangrijkste beroepen weer voor recent afgestudeerden van het HEO tussen 2006 en 20IO. Verreweg de grootste beroepsgroep is die van commercieel medewerkers, waaronder veel adviserende en leidinggevende functies vallen op het gebied van marketing, verkoop, reclame en financiële transacties. In de afgelopen periode waren er ruim 15.000 recent afgestudeerden van het Hoger Economisch Onderwijs werkzaam als commercieel medewerker. Bovendien komt een tamelijk grote groep HEO-afgestudeerden terecht in vergelijkbare functies op middelbaar niveau: de zogenaamde commercieel employés. Hieronder vallen vooral uitvoerende functies in deze vakgebieden. Andere populaire beroepen onder HEO-afgestudeerden zijn assistent accountant, organisatie-adviseur, sociaal-cultureel werker of systeemanalist.

\section{Tabel 1.5}

Aandeel werkende recent afgestudeerden van het HEO per beroep, 2006-2010 (\%)

\begin{tabular}{|l|l|r|r|}
\hline & Beroep: & HEO & HBO totaal \\
$\%$
\end{tabular}

Bron: HBO-Monitor 2006-2010 


\section{De arbeidsmarkt voor afgestudeerden van het HEO}

In hoofdstuk 2 staat de arbeidsmarktintrede van recent afgestudeerden van het Hoger Economisch Onderwijs centraal. In dit hoofdstuk komen verschillende indicatoren aan bod die een indicatie geven over de transitie van het Hoger Economisch Onderwijs naar de arbeidsmarkt over de periode 1998-20I0. Zodoende wordt een beeld verschaft van niet alleen de huidige situatie voor afgestudeerden van het HEO op de arbeidsmarkt, maar ook van de mate waarin die situatie stabiel is, structureel beter of slechter wordt, of gevoelig is voor de conjunctuur. De indicatoren die achtereenvolgens aan bod komen zijn het werkloosheidspercentage, het percentage tijdelijke contracten, zelfstandigen en freelancers, deeltijdwerkers, het niveau en de richting van de huidige functie, het percentage dat de aansluiting tussen onderwijs en arbeidsmarkt als voldoende of goed betiteld, de beloning, de tevredenheid met de huidige baan, het percentage dat spijt heeft van de gevolgde opleiding en tot slot het percentage dat een cursus of bedrijfsopleiding gevolgd heeft. Voor elke indicator wordt de trend voor de recent afgestudeerden van het Hoger Economisch Onderwijs afgezet tegen de trend van de totale groep recent afgestudeerde HBO'ers. De data hebben betrekking op de periode 1998-20I0. Het gaat hierbij om cijfers over het totale Hoger Economisch Onderwijs, wat betekent dat de resultaten voor de specifieke onderliggende opleidingstypen hiervan af kunnen wijken. ${ }^{2}$ In de bijlage zijn voor de periode 2006-20I0 de kernindicatoren werkloosheid, werkzaam in kerndomein, inkomen huidige baan, spijt van de gekozen opleiding en tevredenheid met huidige baan weergegeven voor de afzonderlijke Bachelor-opleidingen van het Hoger Economisch Onderwijs. Deze cijfers worden afgezet tegen het HEO-gemiddelde en het $\mathrm{HBO}$-gemiddelde.

\section{Werkloosheid}

Afgestudeerden van het HEO lijken ( $\mathrm{I}, 5$ jaar na het behalen van het diploma) iets meer last te hebben van de conjunctuur dan andere HBO'ers. Zowel afgestudeerden van het $\mathrm{HEO}$ als de totale groep $\mathrm{HBO}$-afgestudeerden komen tijdens perioden van laagconjunctuur (200I-2004, 2008-20I0) moeilijker aan een baan, maar figuur 2.I laat zien dat afgestudeerden van het HEO het in deze periodes wat dat betreft extra moeilijk hadden. Dit blijkt uit het oplopende verschil in werkloosheidspercentage tussen beide groepen tussen 2001 en 2003, en vanaf 2007/2008. In 2009 bereikte

2. Er zijn branches met een nog hoger aandeel afgestudeerden van het HEO, maar het gaat dan om relatief kleine branches. Derhalve worden branches met minder dan Ioo HEO-afgestudeerden hier buiten beschouwing gelaten. 
het werkloosheids-percentage van HEO-afgestudeerden op het enquêtemoment met $8,0 \%$ zijn hoogste punt sinds 1998 , maar ook in 2010 was nog altijd $7,8 \%$ van de $\mathrm{HEO}$-afgestudeerden werkloos. Uit de figuur is echter tevens af te leiden dat HEO-afgestudeerden niet alleen de nadelen ondervinden van laagconjunctuur, maar dat zij ook meer profiteren van economische groei. Dit blijkt uit de relatief lage werkloosheid onder HEO'ers ten opzichte van het HBO-gemiddelde tussen 1998 en $200 \mathrm{I}$ en de afname van het verschil in werkloosheidspercentages tussen HBO'ers en afgestudeerden van het HEO in de periode 2003-2006. Zie de bijlage voor de werkloosheidspercentages voor de HEO Bachelor-opleidingen.

\section{Figuur 2.1}

Ontwikkeling werkloosheidspercentage op enquêtemoment, 1998-2010

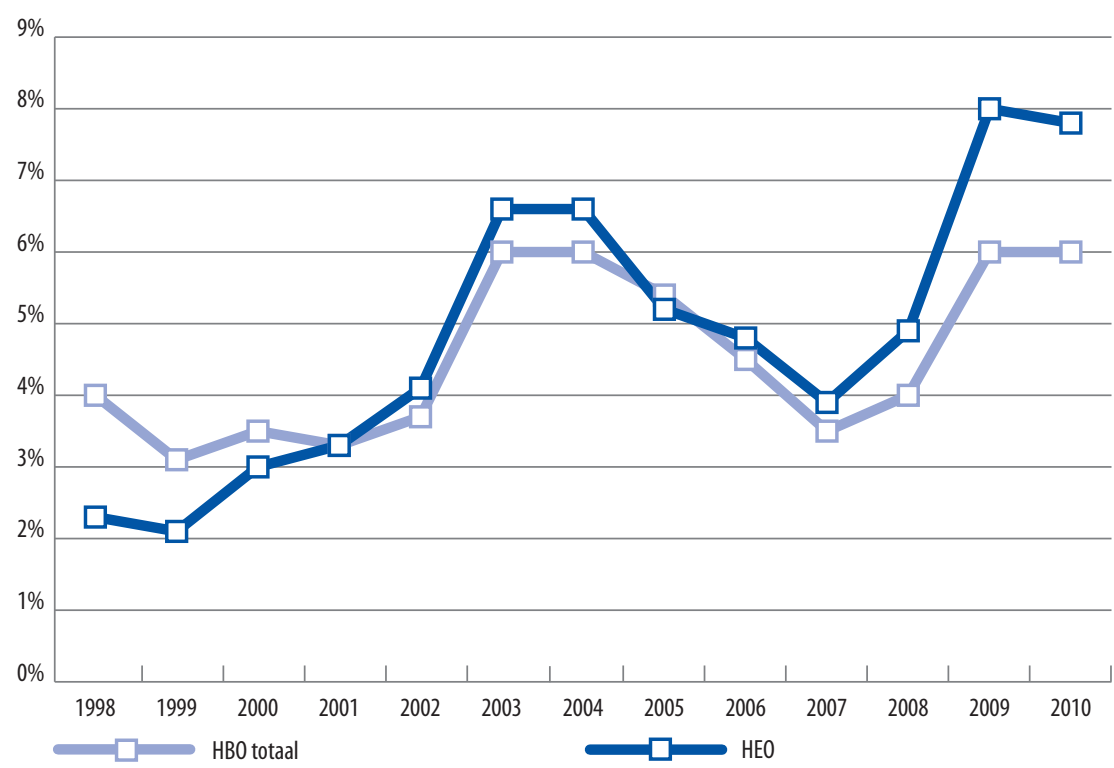

Bron: HBO-Monitor 1998-2010

\section{Tijdelijke aanstelling}

Sinds 1998 kost het meer en meer moeite voor afgestudeerden van het Hoger Economisch Onderwijs om een vaste aanstelling te krijgen. Hoewel het percentage tijdelijke contracten onder recent afgestudeerden sterk afhankelijk is van de conjuncturele situatie, laat figuur 2.2 zien dat dit percentage in de loop der jaren ook structureel aanzienlijk is toegenomen. Dit geldt zowel voor het $\mathrm{HEO}$ als het $\mathrm{HBO}$-gemiddelde. Tussen 2002 en 2005 lag het percentage tijdelijke contracten bij afgestudeerden van het $\mathrm{HEO}$ overigens hoger dan gemiddeld, wat lijkt te duiden op een conjunctuuref- 
fect. In de recente crisis zijn de verschillen tussen $\mathrm{HEO}$ en het $\mathrm{HBO}$ gemiddelde echter niet noemenswaardig.

\section{Figuur 2.2}

Trend tijdelijke aanstelling (\%), 1998-2010

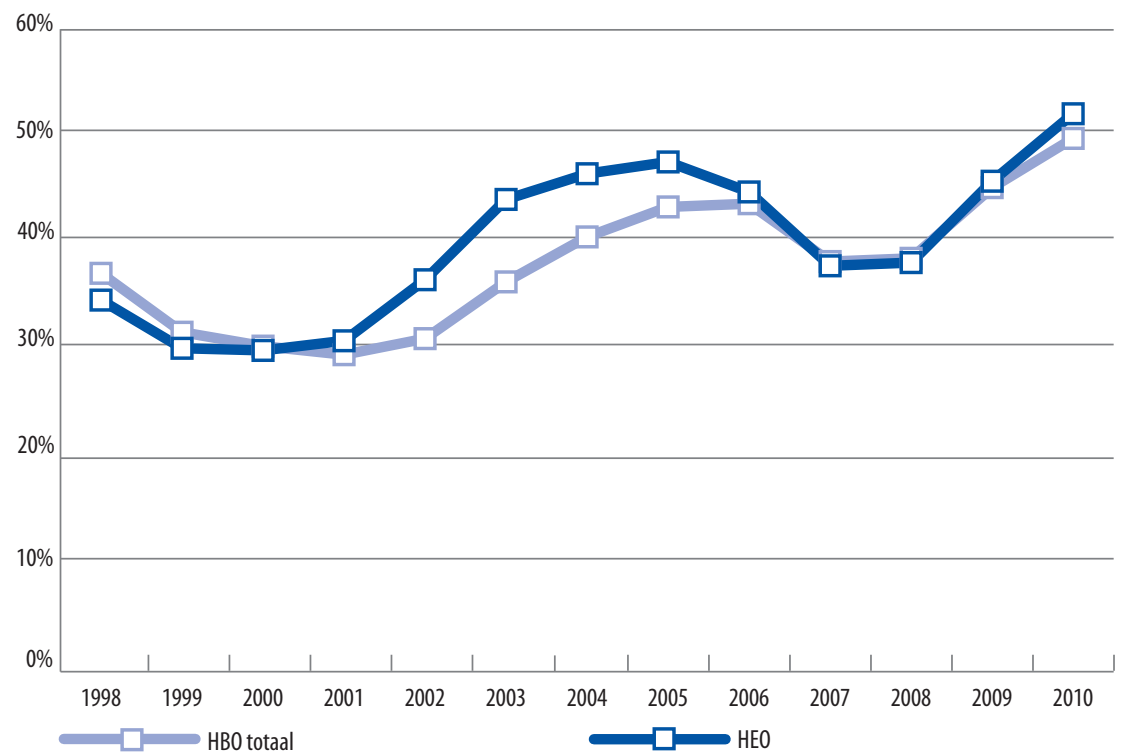

Bron: HBO-Monitor 1998-2010

\section{Werken als zelfstandige/freelancer}

Figuur 2.3 geeft de trend weer in het percentage recent afgestudeerden dat werkzaam is als zelfstandige/freelancer. Voor het $\mathrm{HBO}$ als geheel is dit percentage in de loop der jaren enorm toegenomen, ${ }^{3}$ maar ook de sector economie laat een forse structurele stijging zien, van ruim I\% in 1998 naar ruim $4 \%$ in 20 IO. Voor deze sector lijkt behalve deze algemene stijgende trend ook sprake te zijn van een lichte conjuncturele schommeling. De relatief hardere stijging van het aandeel zelfstandigen/freelancers tijdens laagconjunctuur (2002-2005, 2008-2010) kan er op wijzen dat recent afgestudeerden van het HEO die vanwege economisch zware tijdenmoeite hebben om een contract te bemachtigen uiteindelijk (moeten) besluiten om als zelfstandige aan de slag te gaan. De daling van het aantal zelfstandigen/freelancers tussen 2005 en 2008 lijkt aan te geven dat wanneer de economie weer aantrekt, het percentage HEO'ers dat als zelfstandige/freelancer werkzaam is waarschijnlijk enigszins zal dalen. Echter, aangezien er over het algeheel een stijgende trend zichtbaar is, is het vermoeden dat het percentage waarschijnlijk niet zo ver zal dalen als het niveau van voor de recente crisis.

3. Vooral in de $\mathrm{HBO}$-sectoren kunst en landbouw is dit percentage anno $20 \mathrm{oro}$ erg hoog. 
Figuur 2.3

Trend werkzaam als zelfstandige/freelancer (\%), 1998-2010

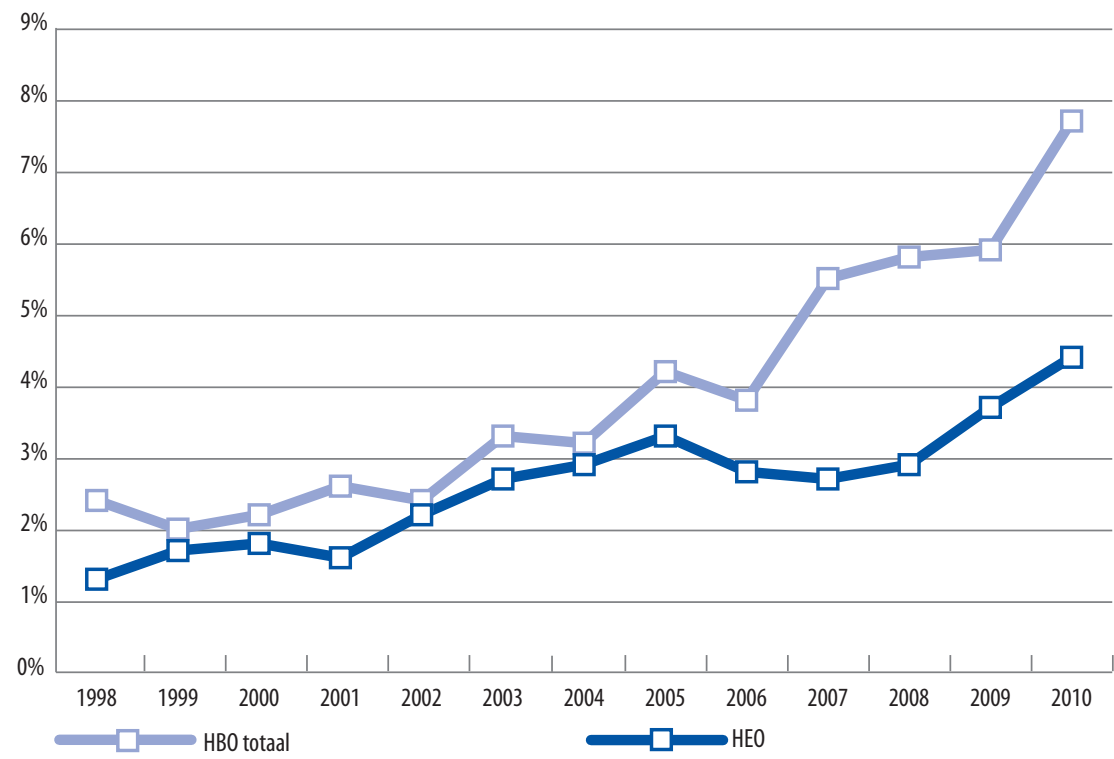

Bron: HBO-Monitor 1998-2010

\section{Parttime werk}

Recent afgestudeerden van het $\mathrm{HEO}$ werken verhoudingsgewijs minder vaak parttime, en dus vaker fulltime dan het $\mathrm{HBO}$-gemiddelde. Onder fulltime wordt verstaan dat zij een baan hebben van meer dan 32 uur per week. Het percentage dat parttime werkt neemt sinds 1998 structureel toe, zowel voor de sector economie als voor het $\mathrm{HBO}$ als geheel (figuur 2.4). Werkte gedurende de gehele periode gemiddeld $\mathrm{i} 2,7 \%$ van de HEO'ers in deeltijd, in 2010 werkte al bijna I op de 5 in een deeltijdfunctie. Ook hier is naast de algemene trend het effect van de conjunctuur duidelijk zichtbaar: in economisch mindere tijden (200I-2004, 2009-20IO) zien we een groei in het percentage dat in deeltijd werkt. Het conjunctuur-effect is overigens wat deeltijd werk betreft net zo sterk voor afgestudeerden van het $\mathrm{HEO}$ als voor de totale groep HBO'ers. Dit blijkt uit de afstand tussen beide lijnen, die de gehele periode vrijwel gelijk blijft. Dat het percentage deeltijdwerkers tijdens lichte economische groei (2006-2008) direct weer afneemt, geeft aan dat de stijging van het aantal deeltijdwerkers slechts gedeeltelijk een vrijwillige keuze betreft. Het impliceert dat er een groep is dat tijdens economische malaise noodgedwongen genoegen moeten nemen met een deeltijd baan, en dat als de economie weer aantrekt, het percentage HEO'ers dat parttime werkt weer zal dalen. Ook hier zal echter het niveau van voor de recente crisis waarschijnlijk niet meer bereikt worden, omdat er tevens sprake is van een algehele stijgende trend. 
Figuur 2.4

Trend parttime werk (\%), 1998-2010

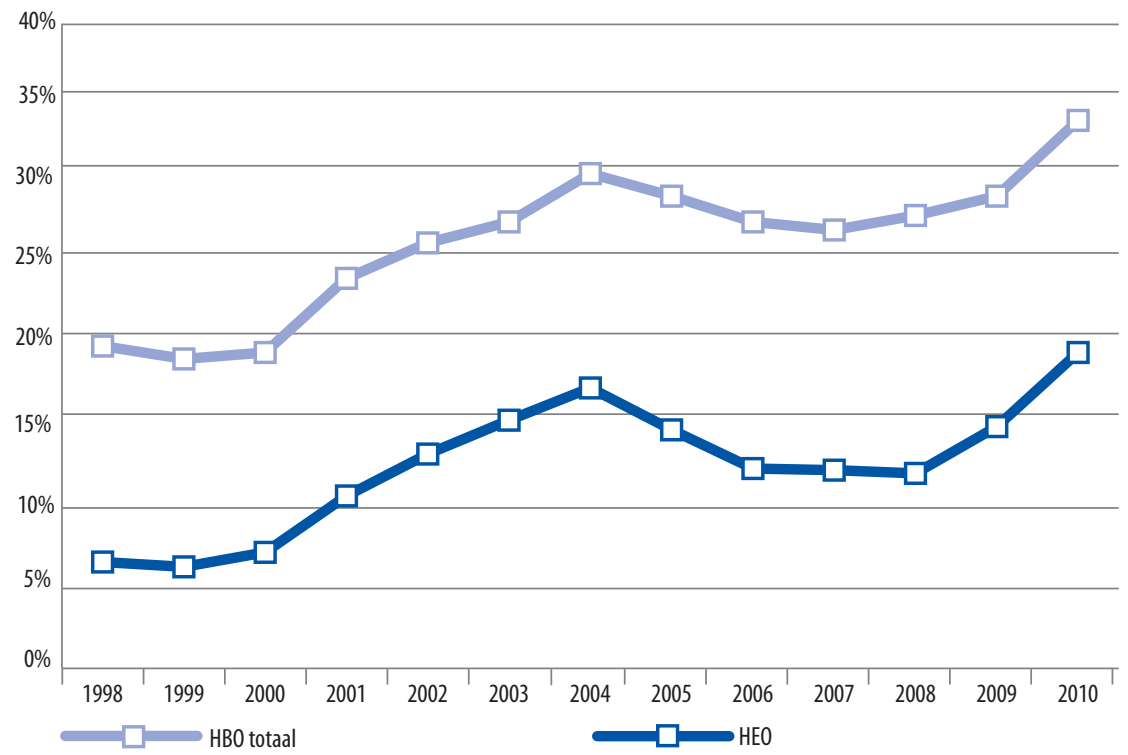

Bron: HBO-Monitor 1998-2010

\section{Niveau en richting huidige functie}

Door verdringingseffecten op de arbeidsmarkt is het mogelijk dat recent afgestudeerden noodgedwongen genoegen moeten nemen met een functie die onder hun niveau is of die buiten hun vakgebied is. In vergelijking met de totale groep HBO-afgestudeerden werken HEO-afgestudeerden tussen 1998 en 2010 iets vaker onder hun niveau. Het verschil in deze zogenaamde onderbenutting is tussen beide groepen echter gering: $22,0 \%$ van de HEO'ers werkt in deze periode onder het niveau, tegenover 20,I\% van de totale groep $\mathrm{HBO}$-afgestudeerden. Hoewel $\mathrm{HEO}$-afgestudeerden niet veel afwijken van het $\mathrm{HBO}$-gemiddelde wat betreft het aandeel dat een baan heeft onder het opleidingsniveau, kan dit niet gezegd worden van de opleidingsrichting. Starters op de arbeidsmarkt met een HEO-diploma werken aanzienlijk vaker buiten hun richting dan andere afgestudeerde HBO'ers. Van eerstgenoemden geeft ruim een derde $(34,7 \%)$ aan dat hun werkgever geen specifieke opleidingsrichting of een andere opleidingsrichting voor de huidige functie vereist, terwijl dit gemiddeld $2 \mathrm{I}, 4 \%$ is onder de totale groep starters met een $\mathrm{HBO}$-opleiding.

Wanneer opleidingsniveau en -richting gecombineerd worden, kan achterhaald worden of de recent afgestudeerden binnen hun kerndomein werkzaam zijn. Met een baan binnen het kerndomein wordt bedoeld dat iemand een baan heeft op minimaal zijn opleidingsniveau, in dit geval $\mathrm{HBO}$, en tegelijkertijd in dezelfde of verwante richting als de voltooide opleidingsrichting. 
Recent afgestudeerden van het $\mathrm{HEO}$ werken vlak na afstuderen relatief weinig in hun kerndomein. Van degenen die tussen 1998 en 2010 afstudeerden van het HEO geeft iets meer dan de helft aan (56\%) vlak na afstuderen een baan te hebben (gehad) op minimaal HBO-niveau én binnen de eigen of daaraan verwante opleidingsrichting (figuur 2.5). Vergeleken met de andere $\mathrm{HBO}$ sectoren is dit percentage relatief laag; alleen bij $\mathrm{HBO}$ gedrag en maatschappij ligt dit percentage nog lager (54\%). Het hoogste percentage vinden we bij de $\mathrm{HBO}$ sector onderwijs, waar $87,0 \%$ binnen het kerndomein werkt. Gemiddeld genomen heeft twee derde van de totale groep recent afgestudeerden van het $\mathrm{HBO}$ een baan in het kerndomein.

\section{Figuur 2.5}

Vereist niveau en vereiste richting van de baan, 1998-2010

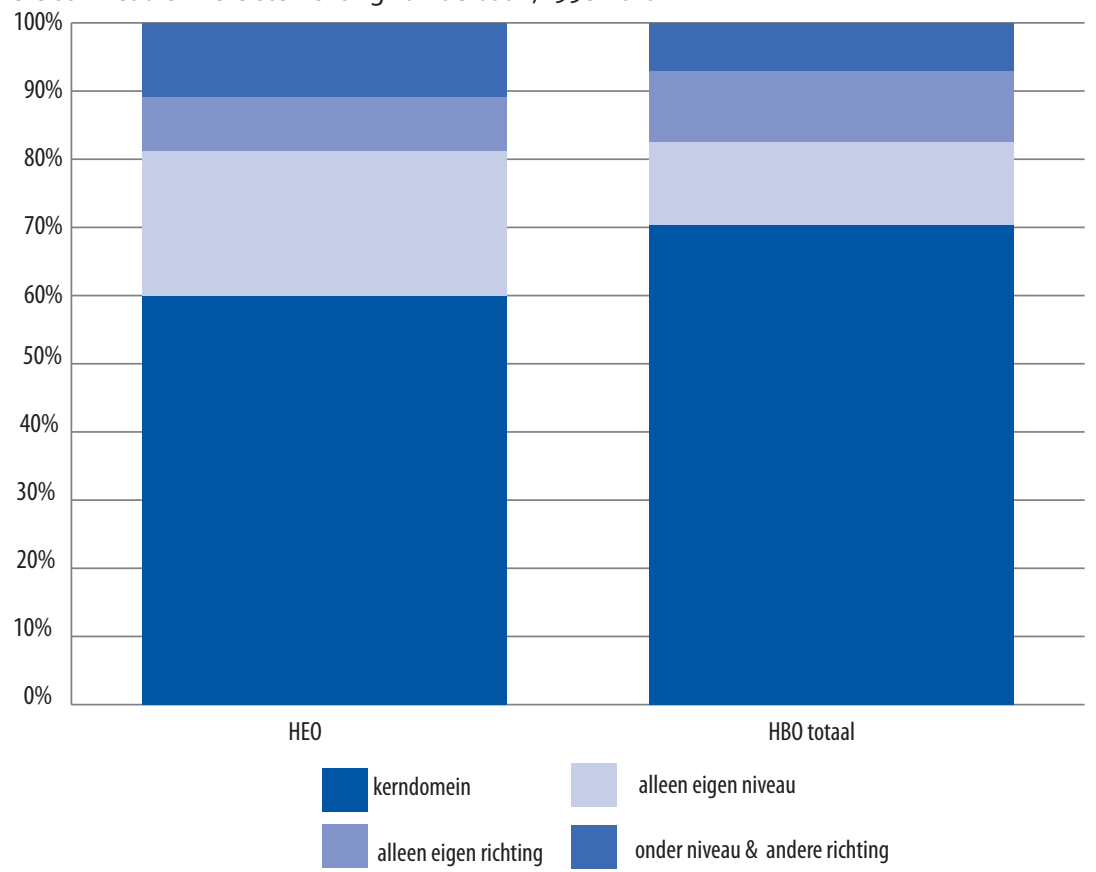

Bron: HBO-Monitor 1998-2010

Vaak werken pas afgestudeerden van het HEO wel op minimaal hun eigen niveau, maar hebben zij een baan in een niet-economische richting. Ten opzichte van het HBO-gemiddelde hebben HEO-afgestudeerden zelfs bijna IO\%-punt vaker een baan op minimaal het eigen niveau, maar niet in de eigen of een verwante richting ('alleen eigen niveau'). Dit kan deels verklaard worden door het generieke karakter van veel $\mathrm{HEO}$-opleidingen. Dit in tegenstelling tot opleidingen in sectoren als gezondheidszorg en onderwijs die veel specifieker voor de betreffende sectoren opleiden. Ook werken afgestudeerden van het HEO I, 5 jaar later vaker dan gemiddeld zowel onder hun niveau alsook in een andere richting. In de bijlage zijn de resultaten met betrek- 
king tot het percentage dat binnen het kerndomein werkzaam is weergegeven per HEO Bachelor-opleiding.

Veel van de overige baankenmerken van afgestudeerden worden in sterke mate bepaald door de vraag of zij binnen hun kerndomein werken of daarbuiten. Om dit te illustreren laat tabel 2.I een aantal baankenmerken zien voor afgestudeerden van wie het huidige werk zowel naar niveau als naar richting aansluit bij de gevolgde opleiding, evenals voor afgestudeerden voor wie geldt dat de opleidingsrichting, het opleidingsniveau, óf beide niet aansluiten bij de door hen gevolgde HBO-opleiding.

Tabel 2.1

Baankenmerken naar werken in/buiten kerndomein, 2006-2010

\begin{tabular}{|c|c|c|c|c|c|c|}
\hline & $\begin{array}{r}\text { zelfstandige/ } \\
\text { freelancer } \\
(\%)\end{array}$ & $\begin{array}{r}\text { tijdelijke } \\
\text { aanstelling } \\
(\%)\end{array}$ & $\begin{array}{r}\text { part-time } \\
\text { werk } \\
(\%)\end{array}$ & $\begin{array}{r}\text { aansluiting } \\
\text { opleiding-werk } \\
(\%)\end{array}$ & $\begin{array}{r}\text { gem. reëel } \\
\text { uurloon } \\
(€)\end{array}$ & $\begin{array}{r}\text { tevreden } \\
\text { met baan } \\
(\%)\end{array}$ \\
\hline \multicolumn{7}{|l|}{ HEO } \\
\hline $\begin{array}{l}\text { minimaal eigen niveau + eigen/ } \\
\text { verwante richting }\end{array}$ & 2,8 & 40,4 & 12,0 & 82,4 & 13,99 & 70,6 \\
\hline alleen op eigen niveau & 3,9 & 44,0 & 12,7 & 59,2 & 13,84 & 58,4 \\
\hline alleen in eigen/verwante richting & 1,6 & 53,3 & 15,1 & 70,9 & 12,78 & 46,1 \\
\hline onder niveau + andere richting & 2,0 & 55,7 & 29,4 & 34,8 & 11,53 & 30,3 \\
\hline totaal & 2,9 & 43,8 & 14,3 & 71,4 & 13,59 & 61,6 \\
\hline \multicolumn{7}{|l|}{ HBO totaal } \\
\hline $\begin{array}{l}\text { minimaal eigen niveau + eigen/ } \\
\text { verwante richting }\end{array}$ & 5,2 & 41,7 & 28,6 & 84,4 & 14,08 & 74,4 \\
\hline alleen op eigen niveau & 6,3 & 44,3 & 17,5 & 58,8 & 13,72 & 61,9 \\
\hline alleen in eigen/verwante richting & 3,4 & 43,6 & 41,5 & 69,8 & 12,67 & 51,5 \\
\hline onder niveau + andere richting & 3,7 & 54,7 & 38,0 & 32,8 & 11,33 & 33,1 \\
\hline totaal & 5,1 & 43,1 & 29,2 & 76,1 & 13,69 & 67,6 \\
\hline
\end{tabular}

Bron: HBO-monitor 2006-2010

Afgestudeerden die op minimaal hun eigen niveau werken doen dat veel vaker als zelfstandige of freelancer dan afgestudeerden die onder hun niveau werken. Interessant genoeg geldt dat vooral als ze buiten hun eigen opleidingsrichting werken. Werken op minimaal het eigen opleidingsniveau betekent tevens een beduidend kleinere kans op een tijdelijke en/of parttime aanstelling. Weinig verrassend is de bevinding dat afgestudeerden die helemaal binnen hun eigen kerndomein werken veel vaker oordelen dat de aansluiting tussen de $\mathrm{HBO}$-opleiding en hun werk voldoende of goed is. Dit geldt voor zowel afgestudeerden van het $\mathrm{HEO}$ als voor de totale groep $\mathrm{HBO}$ afgestudeerden. Afgestudeerden die onder hun niveau maar binnen hun eigen richting werken, oordelen veel vaker dat de aansluiting voldoende of goed is dan afgestudeerden die op minimaal hun eigen niveau maar buiten hun eigen richting werken. In termen van beloning en baantevredenheid ligt dit echter precies andersom. Ook dit geldt zowel voor de $\mathrm{HEO}$ sector als voor het $\mathrm{HBO}$-gemiddelde. 
Figuur 2.6 geeft aan hoe het percentage afgestudeerden dat binnen het kerndomein werkt veranderd is over de tijd. Dit percentage lijkt enigszins mee te bewegen met de conjunctuur, maar er is bovendien sprake van een heel licht stijgende trend. Werkte in 2004 bijvoorbeeld de helft van alle pas afgestudeerden van het HEO in het kerndomein, enkele jaren later was dit in 2008 gestegen tot $63 \%$. Sindsdien is het door de invloed van de economische crisis weer moeilijker geworden om een baan op het eigen niveau en binnen het eigen vakgebied te vinden, wat resulteert in een daling van het percentage werkenden in het kerndomein. Afgestudeerden van het HEO lijken wat dit betreft wat harder te worden getroffen door laagconjunctuur dan de gemiddelde HBO'er. Dit is af te leiden uit de groeiende afstand tussen de lijnen in de periode 200I-2005 en sinds 2008. Tijdens economisch wat betere tijden (I998-2000, 2006-2008) herstellen ze zich wel sneller dan de gemiddelde HBO'er, maar ze profiteren niet extra van hoogconjunctuur. In deze periodes blijft de afstand tussen de lijnen immers gelijk.

\section{Figuur 2.6}

Trend werkzaam in kerndomein (\%), 1998-2010

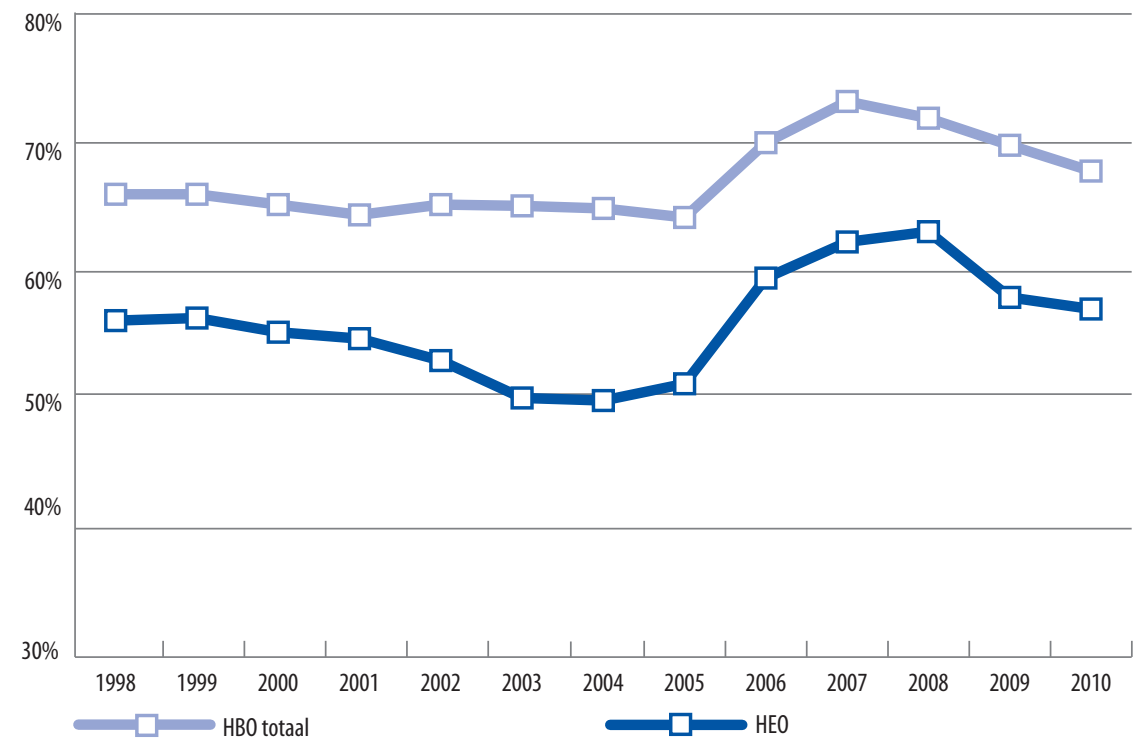

Bron: HBO-Monitor 1998-2010

\section{Aansluiting opleiding-werk}

In het algemeen oordelen recent afgestudeerden van het $\mathrm{HEO}$ minder gunstig over de aansluiting tussen de gevolgde opleiding dan andere HBO'ers. Tussen 1998 en 2010 beoordeelt driekwart van de afgestudeerden van het $\mathrm{HEO}$ de aansluiting tussen de afgeronde opleiding en de baan als voldoende of goed, tegenover 8 op de Io afge- 
studeerden van het gehele $\mathrm{HBO}$. Voor het totale $\mathrm{HBO}$, maar in het bijzonder voor het $\mathrm{HEO}$, is bovendien sprake van een dalende trend. Hoewel de conjuncturele situatie van invloed is op de perceptie van de aansluiting, wijst dit er in algemene zin op dat de aansluiting de laatste jaren als minder goed ervaren wordt. In 2010 beoordeelde bijna een derde van de HEO-afgestudeerden de aansluiting tussen opleiding en werk als matig of slecht. Bij het totale $\mathrm{HBO}$ was dit een kwart. De relatief sterkere daling van de tevredenheid met de aansluiting onder HEO'ers ten opzichte van het $\mathrm{HBO}$-gemiddelde zou kunnen samenhangen met de eerdere bevinding dat HEO'ers structureel minder vaak binnen hun kerndomein werken dan de gemiddelde HBO'er. Vooral voor afgestudeerden die buiten de opleidingsrichting werken is het niet verwonderlijk als ze de aansluiting van hun opleiding en hun werk minder goed zouden vinden.

Figuur 2.7

Trend aansluiting tussen HBO-opleiding en werk is voldoende/goed (\%), 1998-2010

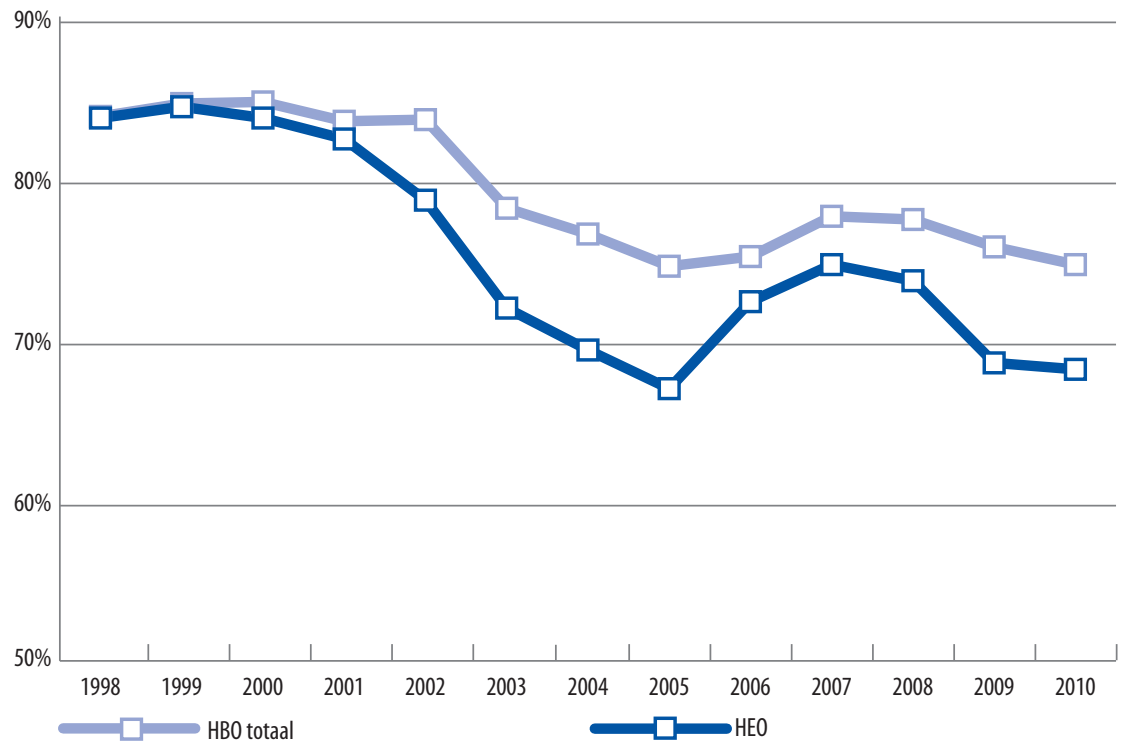

Bron: HBO-Monitor 1998-2010

\section{Inkomen huidige baan}

Het reële bruto uurloon van de totale groep HBO-afgestudeerden is erg conjunctuurgevoelig (figuur 2.8). Dit geldt in nog sterkere mate voor de groep afgestudeerden van het HEO. Tot en met 2005 lagen de reële bruto uurlonen van HEO-afgestudeerden doorgaans een flink stuk onder het HBO-gemiddelde. Dit was met name het geval wanneer er sprake was van laagconjunctuur. Vervolgens leek het HEO een behoorlijke inhaalslag te maken en waren de lonen vrijwel gelijk aan, en in 2007 zelfs iets hoger 
dan, het totale HBO. Met de intrede van de crisis zien we de verschillen echter weer oplopen, ten nadele van het HEO. Evenals bij veel andere arbeidsmarktindicatoren wijst dit erop dat recent afgestudeerden van het HEO extra hard worden geraakt door laagconjunctuur. Tussen 1998 en 2010 is het reële bruto uurloon van recent afgestudeerde HBO'ers overigens marginaal gestegen. Voor HEO-afgestudeerden nam dit toe met 52 eurocent, voor het totale $\mathrm{HBO}$ was dit 46 eurocent. De over het algemeen lagere bruto uurlonen voor HEO'ers dan voor het $\mathrm{HBO}$-gemiddelde, zou kunnen samenhangen met de bevinding dat HEO'ers vaker dan gemiddeld buiten hun opleidingsrichting en/of onder hun niveau werkzaam zijn. Het zou niet verwonderlijk zijn als een afgestudeerde die in een functie buiten zijn kerndomein werkzaam is, minder verdient dan iemand die wel binnen zijn kerndomein werkt. Zie de bijlage voor de gemiddelde bruto uurlonen per HEO Bachelor-opleiding.

Figuur 2.8

Reële ${ }^{4}$ bruto uurloon huidige baan (euro), 1998-2010

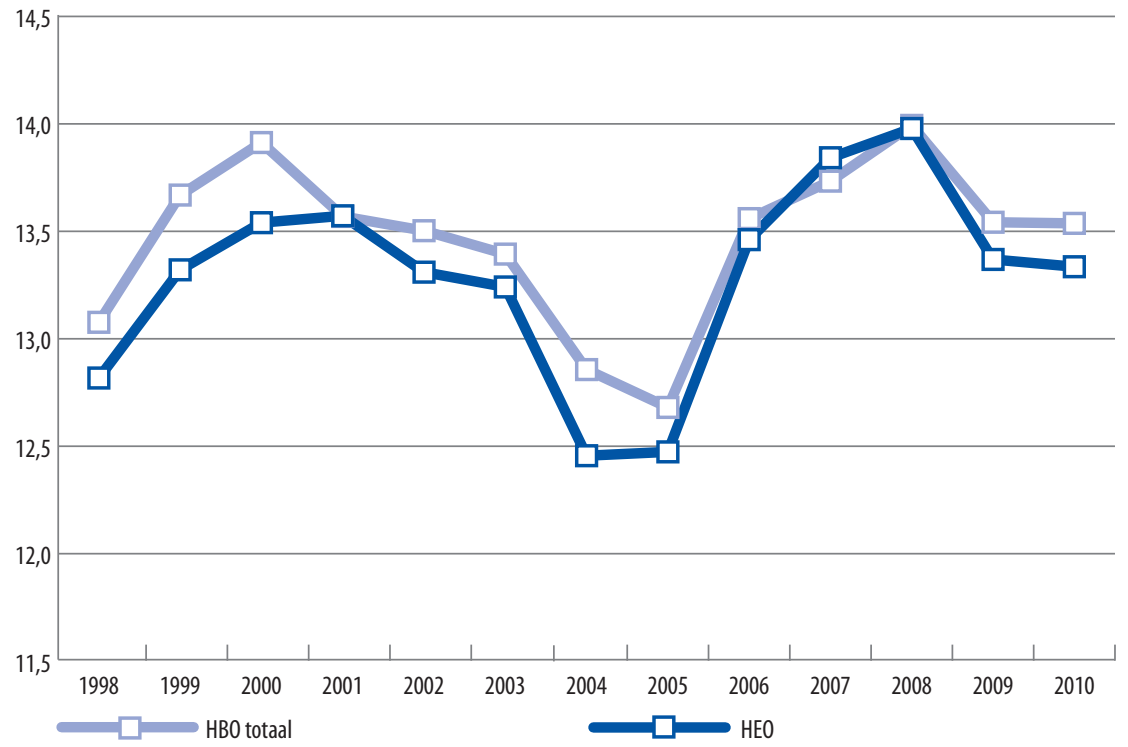

Bron: HBO-Monitor 1998-2010

Tevredenheid met huidige baan

Ook de tevredenheid met de huidige baan geeft een indicatie van de arbeidsmarktintrede van recent afgestudeerde HBO'ers. Afgestudeerden van het $\mathrm{HEO}$ zijn in vergelijking met de totale groep werkende HBO'ers I, 5 jaar na het verlaten van de opleiding minder vaak tevreden met de huidige baan. Terwijl twee derde $(67,3 \%)$ van de totale groep pas afgestudeerde HBO'ers tevreden of zeer tevreden is met de huidige baan, is

4. Hierbij is gecorrigeerd voor de jaarlijkse inflatie zoals gemeten door het CBS. 
dit onder HEO-afgestudeerden gemiddeld 6I,2\%. De tevredenheid onder HEO'ers lijkt ook iets gevoeliger voor de conjunctuur dan die van de gehele groep HBO'ers. Aangezien de HEO'ers gemiddeld genomen, en vooral in tijden van economische malaise, minder vaak in hun kerndomein werken, minder verdienen en vaker tijdelijke aanstellingen hebben, is het niet verwonderlijk dat ze ook minder tevreden zijn over hun baan. Zie de bijlage voor de tevredenheidspercentages per HEO Bacheloropleiding.

\section{Figuur 2.9}

(Zeer) tevreden met huidige functie (\%), 2003-2010

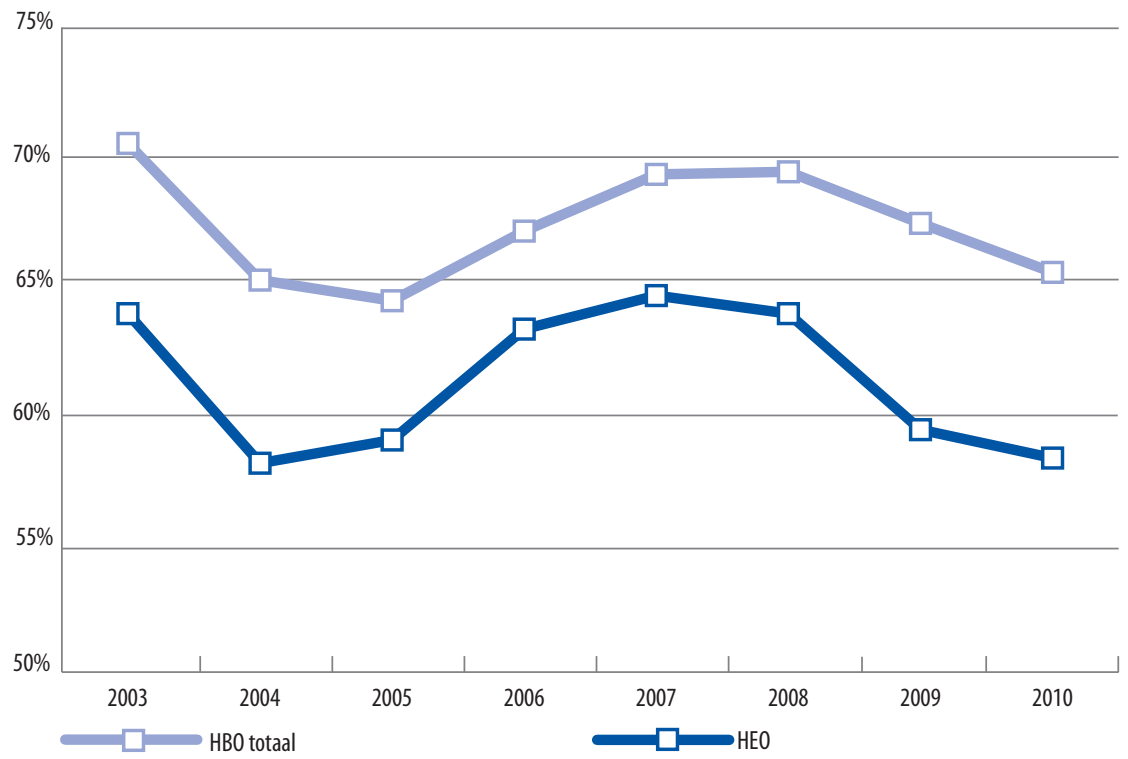

Bron: HBO-Monitor 2003-2010

\section{Spijt van de gekozen opleiding}

Op de vraag of afgestudeerden achteraf gezien opnieuw voor de gevolgde opleiding zouden kiezen of dat zij ditmaal voor een andere opleiding zouden kiezen, antwoorden $\mathrm{HEO}$-afgestudeerden iets minder positief dan andere HBO'ers. Gemiddeld genomen heeft in de periode 1998-20IO ruim I op de 4 HEO-afgestudeerden spijt van de gekozen opleiding. Bij het gehele $\mathrm{HBO}$ is dit $\mathrm{I}$ op de 5 afgestudeerden. Daarnaast is er een licht stijgende trend waarneembaar voor het Hoger Economisch Onderwijs, wat betekent dat het percentage $\mathrm{HEO}$-afgestudeerden dat achteraf gezien voor een andere

5. De variabele tevredenheid met de huidige baan is niet beschikbaar voor eerdere jaren.

Enquêtevraag: Hoe tevreden bent u met uw huidige functie (I 'zeer ontevreden' tot en met 5 'zeer tevreden'. Vermeld is het percentage van antwoordcategorie 4 en 5 . 
dan de gevolgde opleiding zou kiezen enigszins toeneemt over de tijd. Bij het totale $\mathrm{HBO}$ zien we echter niet dat het percentage dat achteraf spijt heeft van de gekozen opleiding stijgt, waardoor het verschil tussen $\mathrm{HEO}$ en het $\mathrm{HBO}$ gemiddelde in het percentage dat achteraf spijt heeft van de gekozen opleiding, steeds verder toeneemt. Dit zou kunnen samenhangen met de stijgende werkloosheid onder afgestudeerden van het HEO. Zie de bijlage voor het percentage dat achteraf gezien spijt heeft van de gekozen opleiding, uitgesplitst naar HEO Bachelor-opleiding.

\section{Figuur 2.10}

Achteraf gezien spijt van de gekozen opleiding (\%), 1998-2010

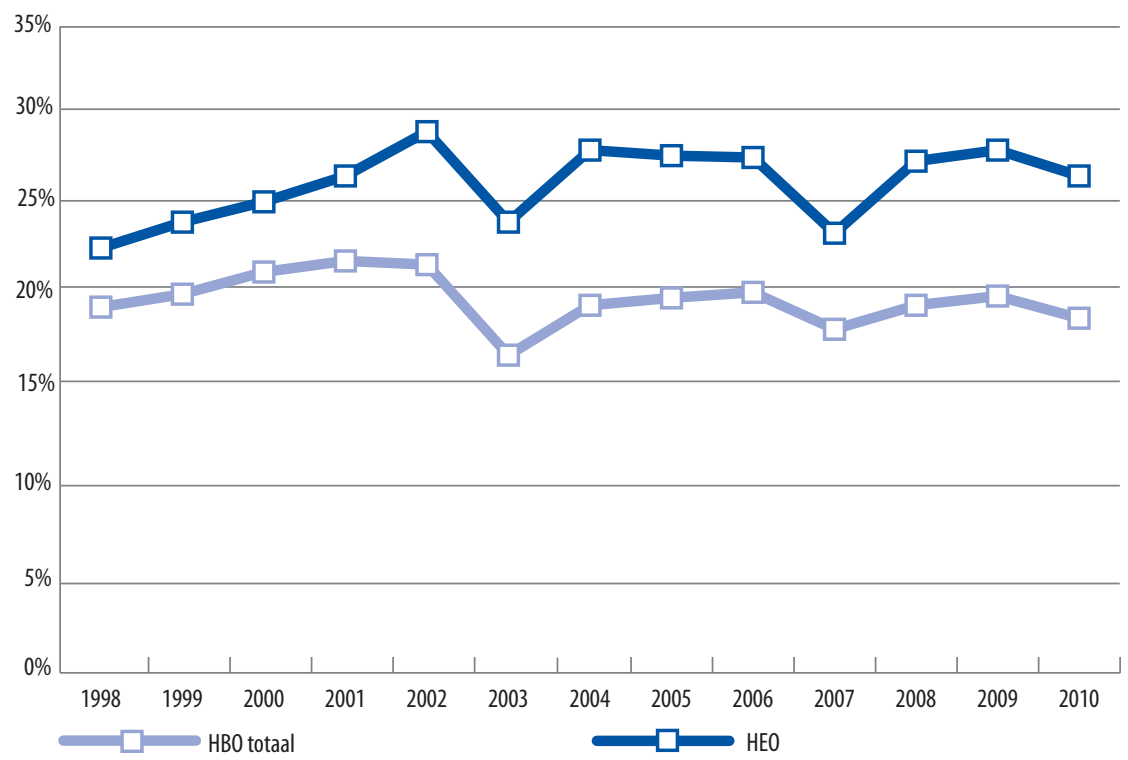

Bron: HBO-Monitor 1998-2010

\section{Cursus of bedrijfsopleiding gevolgd}

Tegenwoordig komt steeds meer nadruk te liggen op het belang van Leven Lang Leren, waarbij de continue ontwikkeling van menselijk kapitaal tijdens de loopbaan centraal staat. In dit kader is het ook interessant om te bekijken of starters op de arbeidsmarkt die een HEO-opleiding gevolgd hebben zo kort na afstuderen al een cursus of bedrijfsopleiding van hun werkgever mochten volgen. Dit blijkt het geval te zijn voor circa de helft van de werkende HEO'ers, maar het percentage neemt af over de tijd. Tevens lijkt het percentage gevoelig te zijn voor de conjunctuur. Tot en met 2003 daalde het percentage recent afgestudeerden dat een training of cursus gevolgd heeft. Voor 2003 lag dit percentage bovendien hoger onder HEO'ers dan onder andere HBO'ers. Hierna steeg het percentage voor beide tot en met 2007 waarna er opnieuw een daling plaatsvond. Daarbij valt wederom op dat HEO'ers meer last van de crisis lijken te hebben. 
Figuur 2.11

Cursus of bedrijfsopleiding gevolgd (\%), 1998-2010

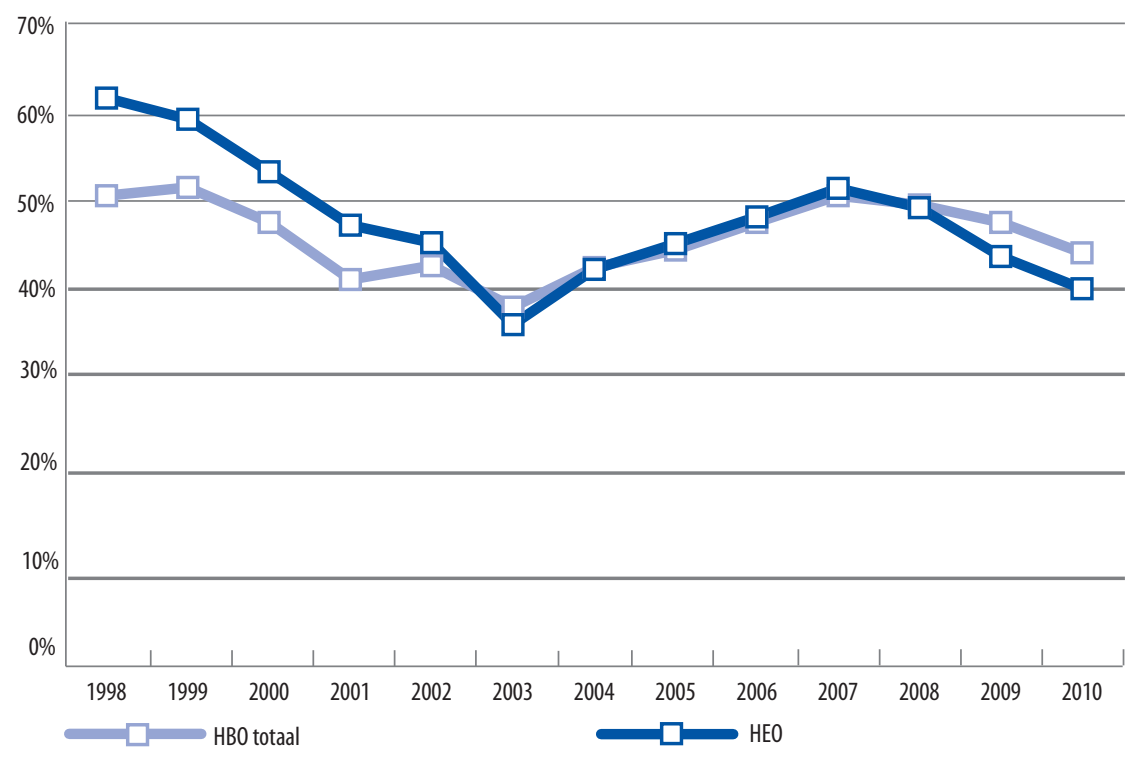

Bron: HBO-Monitor 1998-2010 



\section{Arbeidsmarktdynamiek}

In hoofdstuk 3 staat de arbeidsmarktdynamiek van de economische sector centraal. Allereerst worden in paragraaf 3.I de verwachte arbeidsmarktperspectieven tot 2016 voor $\mathrm{HBO}$-afgestudeerden met een opleiding economie besproken. Hierna komen de uitwijkmogelijkheden en substitutiemogelijkheden naar beroep aan bod in respectievelijk paragraaf 3.2 en 3.3. Deze geven aan of economische opleidingen breder of smaller worden.

\subsection{Indicator toekomstig arbeidsmarktperspectief (ITA) ${ }^{6}$}

Tweejaarlijks biedt ROA een overzicht van de huidige en toekomstige arbeidsmarktontwikkelingen. Een belangrijk onderdeel hierin zijn de arbeidsmarktperspectieven van schoolverlaters. Het toekomstig arbeidsmarktperspectief geeft voor de verschillende opleidingstypen de verhouding weer tussen vraag en aanbod van schoolverlaters en afgestudeerden in de prognoseperiode. In de meest recente versie gaat het om de periode 20II-20I6. De vraag-en aanbodprognoses zijn gebaseerd op de actuele arbeidsmarktpositie van een opleiding. Als het arbeidsmarktperspectief van een opleiding slecht is, betekent dit dat er de komende jaren veel meer aanbod van nieuwkomers zal zijn dan dat er baanopeningen zullen ontstaan. Hierdoor zal de arbeidsmarktpositie van deze afgestudeerden verslechteren. Deze verslechtering kan tot uiting komen in een hogere werkloosheid, maar door aanpassingsprocessen op de arbeidsmarkt kan de verslechtering van de arbeidsmarktsituatie ook leiden tot het moeten aanvaarden van banen op een lager niveau, tegen een lagere beloning of bijvoorbeeld een stijging van het aantal tijdelijke contracten. Omgekeerd zal een goed perspectief leiden tot een grotere kans op werk, maar ook tot een verbeterde positie op andere punten.

Het toekomstig arbeidsmarktperspectief per opleidingstype wordt bepaald door middel van de Indicator Toekomstig Arbeidsmarktperspectief (ITA), die is gedefinieerd als de verhouding tussen enerzijds de verwachte arbeidsmarktinstroom van afgestudeerden en het aantal kortdurig werklozen en anderzijds de verwachte baanopeningen

6. Zie voor meer informatie over de arbeidsmarktperspectieven van schoolverlaters: ROA (2OII), De arbeidsmarkt naar opleiding en beroep tot 2016, ROA-R-20II/8, Maastricht University. 
en de passieve substitutievraag. ${ }^{7}$ Naarmate de waarde van de indicator hoger is wordt het perspectief slechter. De bijbehorende kwalitatieve typering van de arbeidsmarktperspectieven luidt respectievelijk zeer goed, goed, redelijk, matig of slecht.

Ongeacht het opleidingsniveau zijn de arbeidsmarktperspectieven tot 2016 matig voor de sector economie. Evenals op VMBO-, MBO- en WO-niveau geldt namelijk ook voor afgestudeerden van het Hoger Economisch Onderwijs dat de arbeidsmarktperspectieven tot 2016 niet zo gunstig zijn. Met een ITA van I,II kunnen de perspectieven van afgestudeerde HEO'ers tot 2016 als matig getypeerd worden. Dit wordt veroorzaakt door het feit dat de arbeidsmarktinstroom van HEO'ers gemiddeld is, terwijl de werkgelegenheidsgroei en de vervangingsvraag lager dan gemiddeld zijn. In algemene zin kunnen nieuwe instromers op de arbeidsmarkt met een $\mathrm{HBO}$-opleiding juist goede arbeidsmarktperspectieven tegemoet zien. De ITA voor deze totale groep afgestudeerden van het hoger beroepsonderwijs bedraagt 0,99.

\section{Tabel 3.1}

Indicator Toekomstige Arbeidsmarktperspectieven (ITA) voor afgestudeerden van het Hoger Economisch Onderwijs tot 2016, per opleidingstype

\begin{tabular}{|l|r|r|}
\hline Opleiding: & Indicator & Typering \\
\hline HBO economie: & 1,11 & matig \\
\hline accountancy en bedrifseconomie & 1,00 & goed \\
\hline commerciële economie & 1,18 & slecht \\
\hline toerisme en recreatie & 1,27 & slecht \\
\hline recht en bestuur & 1,06 & matig \\
\hline secretariaat & 1,22 & slecht \\
\hline bedrijfkunde & 1,13 & matig \\
\hline Bron: ROA (AIS) & & \\
\hline
\end{tabular}

Tabel 3.I geeft voor de opleidingscategorie HBO economie, alsook de onderliggende opleidingstypen, weer welke arbeidsmarktperspectieven afgestudeerden de komende jaren tegemoet kunnen zien. Hoewel de vooruitzichten voor afgestudeerden van het HEO in het algemeen matig zijn, is er toch sprake van een positieve uitschieter. Afgestudeerden van het opleidingstype accountancy en bedrijfseconomie zullen op de middellange termijn doorgaans redelijk eenvoudig een baan vinden die aansluit bij de gevolgde opleiding. In tegenstelling tot de goede arbeidsmarktperspectieven voor $\mathrm{HBO}$ accountancy en bedrijfseconomie zijn de vooruitzichten van de overige onderliggende opleidingstypen een stuk minder rooskleurig. Zo zijn de arbeidsmarktper-

7. Als gevolg van discrepanties tussen vraag en aanbod op de arbeidsmarkt treden er verschuivingen op in de werkgelegenheidsstructuur. Schoolverlaters in een aanbodoverschotsituatie kunnen anders opgeleiden gaan verdringen, terwijl werkgevers die te kampen hebben met een tekortschietend arbeidsaanbod, personen met een andere opleidingsachtergrond kunnen gaan werven. De vraag die hierdoor verloren gaat of ontstaat wordt aangeduid als het passieve substitutie-effect. Als het passieve substitutie-effect positief is, gaat het om extra baanopeningen als gevolg van tekorten bij andere opleidingen. Een negatief substitutie-effect duidt daarentegen op een verlies aan baanopeningen, omdat men verdrongen wordt door andere opleidingen. 
spectieven voor afgestudeerden van $\mathrm{HBO}$ recht en bestuur alsook $\mathrm{HBO}$ bedrijfskunde matig. Voor $\mathrm{HBO}$ commerciële economie, $\mathrm{HBO}$ secretariaat en $\mathrm{HBO}$ toerisme en recreatie zijn de perspectieven zelfs slecht te noemen.

\subsection{Uitwijkmogelijkheden}

Uitwijkmogelijkheden hebben betrekking op de mate waarin arbeidskrachten met een bepaalde opleidingsachtergrond terecht kunnen komen in andere beroepsgroepen op een aansluitend of hoger functieniveau. Deze maatstaf geeft daarmee aan in hoeverre arbeidskrachten afhankelijk zijn van de arbeidsmarktsituatie in een bepaald beroep. De uitwijkmogelijkheden worden bepaald met behulp van een spreidingsindex. Deze index geeft een indicatie van het aantal beroepsgroepen of bedrijfssectoren waarnaar men kan uitwijken. Door te kijken hoe deze index zich over de tijd ontwikkelt kan een beeld worden verkregen van de mate waarin het beroependomein van opleidingen smaller of breder wordt over de tijd.

Figuur 3.1

Spreidingsindex uitwijkmogelijkheden naar beroepen voor opleidingstypen in het Hoger Economisch Onderwijs, 2001-2010

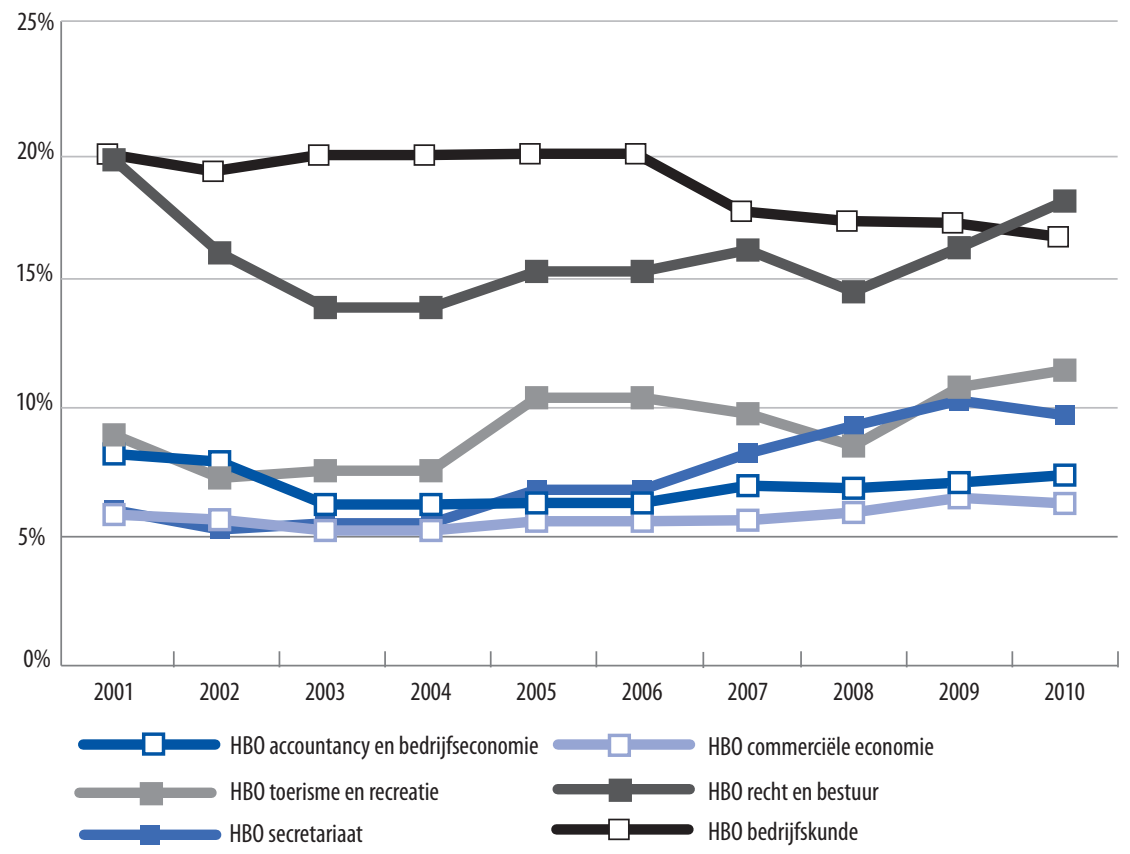

Bron: ROA (AIS) 
Figuur 3.I geeft voor opleidingstypen in het Hoger Economisch Onderwijs weer in welke mate arbeidskrachten met een dergelijke opleidingsachtergrond uitwijkmogelijkheden hebben naar andere beroepen. Uit de figuur blijkt dat afgestudeerden met een opleiding HBO bedrijfskunde de meeste uitwijkmogelijkheden hebben. Wel zijn deze sinds 2007 afgenomen. Dit betekent dat het beroependomein voor afgestudeerden met deze opleidingsachtergrond smaller is geworden en dat zij afhankelijker worden van de arbeidsmarktsituatie binnen het eigen domein. Ondanks dat het bijbehorende beroependomein van deze afgestudeerden de laatste jaren smaller is geworden, is er in algemene zin echter sprake van een relatief groot aantal uitwijkmogelijkheden. Voor $\mathrm{HBO}$ recht en bestuur geldt eveneens dat er relatief veel uitwijkmogelijkheden zijn. Het verloop van de index over de tijd is echter anders. Het beroependomein wordt eerst smaller, maar vooral vanaf 2008 weer breder. Dit laatste kan te maken hebben met het feit dat met de komst van de nieuwe opleiding $\mathrm{HBO}$ rechten, afgestudeerden van dit opleidingstype in aanmerking komen voor beroepen die voorheen uitsluitend het domein waren van mensen met een WO-opleiding rechten. Verder zijn de opleidingstypen $\mathrm{HBO}$ toerisme en recreatie en $\mathrm{HBO}$ secretariaat in de loop van de tijd breder geworden. $\mathrm{HBO}$ accountancy en bedrijfseconomie en $\mathrm{HBO}$ commerciële economie blijven relatief smal qua uitwijkmogelijkheden.

\subsection{Substitutiemogelijkheden}

Substitutiemogelijkheden hebben betrekking op de mate waarin werkgevers voor een bepaald beroep arbeidskrachten kunnen aantrekken met een uiteenlopende opleidingsachtergrond, zodat ze niet enkel afhankelijk zijn van het arbeidsaanbod van een bepaald opleidingstype. Ook de substitutiemogelijkheden worden bepaald met behulp van een spreidingsindex. Door te kijken naar de ontwikkeling van deze index over de tijd kan een beeld worden verkregen van de mate waarin afgestudeerden die zich op deze beroepen richten moeten concurreren met mensen van andere opleidingsachtergronden.

Figuur 3.2 laat de ontwikkeling van de spreidingsindex voor substitutiemogelijkheden zien van belangrijke beroepen in de economische sector. De meeste economische beroepen zijn in dit opzicht breed georiënteerd: er kan doorgaans uit een breed scala aan opleidingen worden gerekruteerd. Verschillende beroepen worden echter smaller in de tijd, in het bijzonder de organisatieadviseurs en leidinggevenden. In mindere mate is dit ook van toepassing op 'boekhouders en secretaresses' en 'receptionisten en administratieve employés'. Het aantal substitutiemogelijkheden voor commercieel medewerkers, commercieel employees en juridisch, bestuurlijk medewerkers neemt, na eerst gedaald te zijn, weer toe tegen het einde van deze periode. 
Figuur 3.2

Spreidingsindex substitutiemogelijkheden voor belangrijke beroepsgroepen in de economische sector, 2001-2010

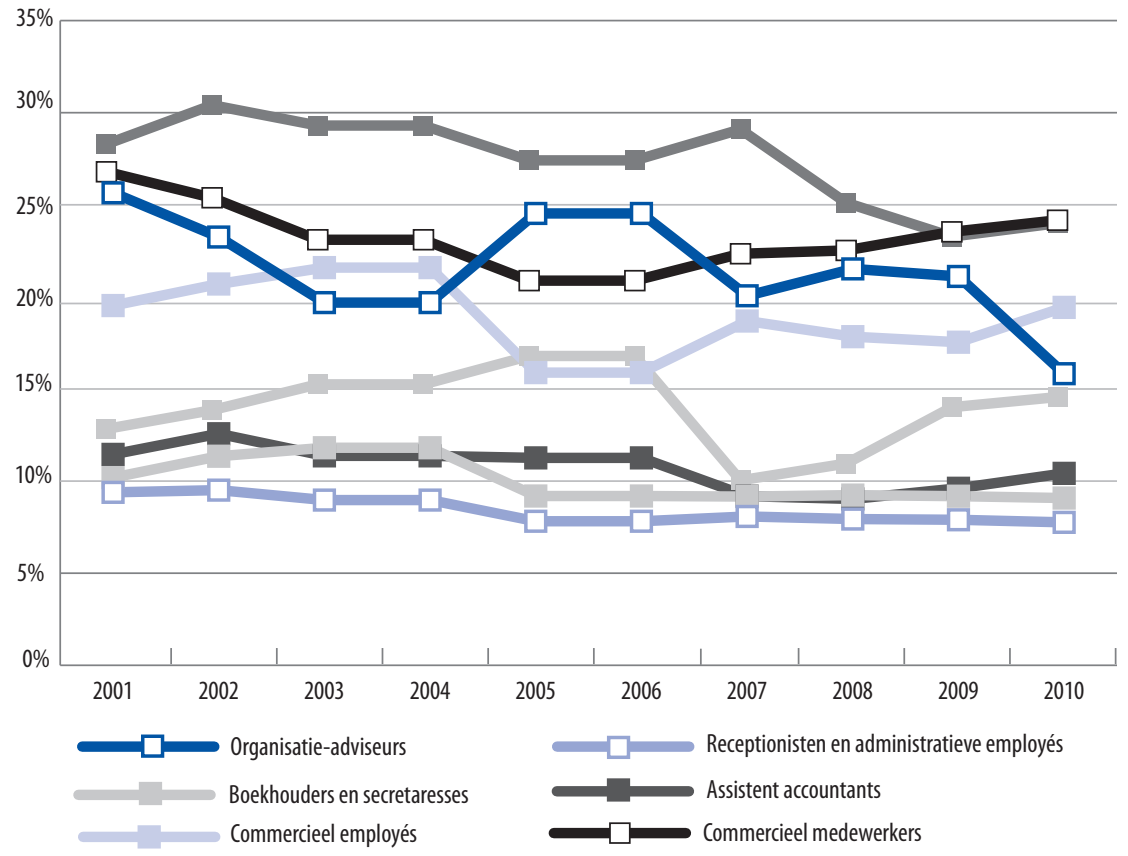

Bron: ROA (AIS) 



\section{Vereiste competenties voor afgestudeerden van het HEO}

In hoofdstuk 2 werd een korte schets gegeven van de arbeidsmarkt voor HEO'ers in het verleden en het heden, en in hoofdstuk 3 werden prognoses gepresenteerd van de verwachte ontwikkeling van de werkgelegenheid in de toekomst. Deze vooral kwantitatieve ontwikkelingen zijn interessant en belangrijk, maar zeggen weinig of niets over hoe het werk in de toekomst in kwalitatieve zin eruit zal zien. In dit hoofdstuk wordt een korte schets gegeven van enkele belangrijke ontwikkelingen en komt aan bod hoe het onderwijsveld op de te verwachten trends kan inspelen bij het opleiden van toekomstige arbeidskrachten voor de economische sector. De focus ligt hierbij op de competenties waar het onderwijsveld zich op moet gaan richten. In paragraaf 4.I worden allereerst enkele algemene en sectorspecifieke trends aangestipt, waarbij de nadruk ligt op mogelijke implicaties van deze trends en ontwikkelingen voor de competenties die door werkgevers worden vereist. In paragraaf $4.2 \mathrm{komt} \mathrm{het}$ vereiste competentieniveau aan bod van recent afgestudeerden die werkzaam zijn in hun kerndomein. Bovendien wordt hier besproken of bepaalde competenties door de jaren heen belangrijker zijn geworden. In paragraaf 4.3 komen vervolgens de ervaren competentietekorten aan bod.

\subsection{Trends en mogelijke implicaties voor vereiste competenties}

Voorbeelden van algemene sector overstijgende trends zijn onder meer demografische ontwikkelingen zoals vergrijzing en ontgroening, voortschrijdende technologische ontwikkelingen, de toenemende invloed van internet en ICT, heterogeniteit van de samenleving, individualisering en mondialisering, klimaatproblematiek en de verschuiving van het economisch zwaartepunt en de daarmee gepaard gaande internationale machtsverhoudingen. Deze raken alle in meer of mindere mate de gehele economische sector.

Al deze trends kunnen op hun beurt vragen om specifieke competenties van de arbeidskrachten die werkzaam zijn in een sector, en dus indirect van invloed zijn op de inrichting van het Hoger Onderwijs. Deze ontwikkelingen leiden er immers toe dat bepaalde competenties belangrijker worden, terwijl andere competenties in de toekomst mogelijkerwijs juist minder van afgestudeerden gevraagd zullen worden. Zeker omdat in hoofdstuk 3 werd geconstateerd dat de arbeidsmarktperspectieven voor afgestudeerden van het $\mathrm{HEO}$ de komende jaren waarschijnlijk zullen verslech- 
teren, is het extra belangrijk dat je als afgestudeerde HEO'er over de juiste (dat wil zeggen: door werkgevers vereiste) competenties beschikt.

Op basis van de literatuur kunnen er drie trends worden gedefinieerd die spelen in de economische sector: verloren vertrouwen, toenemende concurrentie en toenemende invloed van internet en ICT. Hieronder worden deze trends toegelicht waarbij wordt aangegeven wat het belang van deze trends is voor de competenties die nu en in de toekomst van afgestudeerden van het HEO (zullen) worden verwacht.

\section{Verloren vertrouwen}

Om te beginnen heeft de economische sector, en met name de financiële branche, vanwege schandalen en de economische crisis een zware klap gekregen wat betreft het vertrouwen bij consumenten, particulieren en overheden. Dit heeft geleid tot strenger toezicht, een toenemende behoefte aan zekerheid en meer wet- en regelgeving (Rabobank, 20II). Het strengere toezicht en de toename van wet- en regelgeving heeft geleid tot een toename op het gebied van professionalisering en het belang van juridische kennis binnen de economische sector (Rabobank Cijfers en Trends, 20II). Ook worden er strengere eisen gesteld aan de integriteit van instellingen en hun werknemers.

De toenemende aandacht voor professionalisering en het juridisch aspect benadrukt bijvoorbeeld het belang van het kunnen werken volgens richtlijnen. Ook de toenemende behoefte aan zekerheid, de toegenomen behoefte aan integriteit, het afgenomen consumentenvertrouwen (dat ertoe leidt dat consumenten risico's steeds meer willen afdekken) en de toegenomen wet- en regelgeving zorgen ervoor dat deze competentie belangrijker wordt. Tevens zal de toenemende behoefte aan zekerheid ertoe leiden dat men in staat moet zijn problemen en kansen snel te signaleren. Om tegemoet te komen aan de steeds grotere behoefte aan integriteit in de economische sector zou studenten aangeleerd kunnen worden dat zij hun eigen ideeën maar ook de ideeën van anderen ter discussie moeten durven te stellen, en dat ze begrip dienen te tonen voor andere standpunten. Het afgenomen consumentenvertrouwen kan ertoe leiden dat werknemers in de zakelijke of financiële dienstverlening in staat moeten worden geacht om op duidelijke wijze aan klanten uit te leggen wat zij bedoelen, maar ook om op gepaste wijze op te komen voor het eigen standpunt en begrip te tonen voor de standpunten van anderen. Zo kunnen zij het vertrouwen van deze klanten voor zich proberen te winnen. Als hier al in het onderwijs op gefocust wordt kan dit de recent afgestudeerden helpen bij hun arbeidsmarktintrede in de economische sector. Als zij elkaar tijdig durven aan te spreken kunnen excessen mogelijk voorkomen worden.

\section{Toenemende concurrentie}

Een andere ontwikkeling die in de economische sector speelt is de toenemende concurrentie (Berenschot, 20II) en de dalende werkgelegenheid (Berenschot, 20II). 
Dit zorgt ervoor dat innovatie en zich kunnen onderscheiden van de concurrentie belangrijker worden, en daar is creativiteit voor nodig (Rabobank, 2OII).

De toenemende concurrentie vraagt om werkenden die onder druk kunnen functioneren, knopen kunnen doorhakken en hun nek durven uitsteken. Hoewel dit natuurlijk vooral ook 'on-the-job' geleerd kan worden, kan hier in het onderwijs wel al nadruk op gelegd worden door te werken met strikte deadlines en studenten zelf beslissingen te laten nemen bij een casus. Het toenemende belang van creativiteit vraagt om afgestudeerden die in staat zijn om nieuwe ideeën en oplossingen te bedenken, alsook problemen en kansen te signaleren, en ideeën van zichzelf en anderen ter discussie te stellen. Ook het grote aantal zzp'ers en startende ondernemers in de zakelijke dienstverlening vraagt om een adequaat vermogen om problemen en kansen te signaleren, evenals een voldoende niveau aan typische ondernemersvaardigheden zoals het goed kunnen functioneren onder druk, knopen kunnen doorhakken, zelfstandig kunnen werken en je nek durven uitsteken. In het onderwijs kan dit soort competenties wellicht worden gestimuleerd door meer aandacht te besteden aan zelfstandig werken tijdens opdrachten.

\section{Toenemende invloed internet en ICT}

Zoals aan het begin van dit hoofdstuk werd gesteld, is de toenemende invloed van internet en ICT een algemene trend die zich in alle sectoren voordoet. Zo ook in de economische sector, wat ertoe leidt dat producten en diensten steeds vaker via internet worden aangeboden en dat daarbij ook social media worden ingezet (Rabobank, 2OII; ABN Amro, 20II).

Deze digitalisering van de dienstverlening vraagt om ICT-vaardigheden die hier speciaal op gericht zijn. De social media zouden daarbij als apart onderdeel aan bod kunnen komen in het onderwijs als het gaat om het ontwikkelen van communicatievaardigheden. Deze worden namelijk in toenemende mate van belang om zich te kunnen presenteren of om als informatie- of verkoopkanaal in te kunnen zetten in de communicatie naar klanten. Om zich in deze wereld goed staande te kunnen houden is uiteraard meer nodig dan kennis van ICT. Men moet ook in staat zijn om verbanden te leggen tussen de uiteenlopende ideeën die ze hierin tegenkomen en, wanneer ze voor het bedrijf interessante contacten tegenkomen, om goed uit te kunnen leggen waarom het interessant voor hen kan zijn om samen te gaan werken.

Samenvattend geeft tabel 4.I een overzicht van de drie belangrijkste trends voor de economische sector, en de daarbij behorende competenties. Hierbij wordt geopperd welke van de 23 door ROA in de HBO-Monitor onderscheiden competenties beïnvloed kunnen worden door de waargenomen en verwachte ontwikkelingen in de economische sector. 
Tabel 4.1

Belangrijkste trends en bijbehorende competenties die hierdoor beïnvloed kunnen worden

\begin{tabular}{|l|l|}
\hline Ontwikkelingen en trends: & Vereiste competenties: \\
\hline Verloren vertrouwen & Vermogen om conform budget, planning of richtlijnen te werken \\
\hline & Vermogen om problemen en kansen te signaleren \\
\hline Bereidheid om ideeën van uzelf en anderen ter discussie te stellen \\
\hline Bereidheid om begrip te tonen voor andere standpunten \\
\hline Vermogen om aan anderen duidelijk te maken wat u bedoelt \\
\hline Bereidheid om op te komen voor uw eigen standpunt \\
\hline Vermogen om onder druk goed te functioneren \\
\hline Vermogen om knopen door te hakken \\
\hline Bereidheid om uw nek uit te steken \\
\hline Toenemende concurrentie & Vermogen om problemen en kansen te signaleren \\
\hline Vermogen om verbanden te leggen tussen verschillende zaken \\
\hline Vermogen om nieuwe ideeën en oplossingen te bedenken \\
\hline Bereidheid om ideeën van uzelf en anderen ter discussie te stellen \\
\hline Vermogen om onder druk goed te functioneren \\
\hline Vermogen om knopen door te hakken \\
\hline Vermogen om zelfstandig de werkzaamheden uit te voeren \\
\hline Bereidheid om uw nek uit te steken \\
\hline
\end{tabular}

\subsection{Vereist niveau competenties}

In deze paragraaf wordt empirisch onderzocht of er indicaties zijn dat dergelijke ontwikkelingen inderdaad gevolgen hebben voor de competenties waarover afgestudeerden van de sector HEO dienen te beschikken. Daarom wordt voor de 23 onderscheiden competenties ingegaan op het vereiste niveau in de huidige functie voor afgestudeerden die in hun kerndomein werkzaam zijn. Tabel 4.2 toont het vereiste competentieniveau op basis van een 5-puntschaal die loopt van I 'matig niveau vereist' tot en met 5 'uitmuntend niveau vereist'. Om een beeld te krijgen van de mate waarin de competentievereisten aan het veranderen zijn, wordt tevens de trend in deze vereisten berekend. Zo wordt een beeld gegeven van de gemiddelde jaarlijkse toe- of afname. De trend wordt alleen getoond wanneer deze statistisch significant is. ${ }^{8}$ De

8. De trends zijn berekend door middel van regressieanalyses, waarbij het effect van het aantal jaren verstreken vanaf $2004(2004=0, \ldots 2010=6)$ op het vereiste niveau van de verschillende competenties is berekend. Om het effect van mogelijke verschuivingen in de compositie van de sector naar opleiding of hogeschool te voorkomen, worden dummy's opgenomen voor alle opleidingen en scholen die in de sector zijn vertegenwoordigd. 
competenties waarvan in de vorige paragraaf werd geconstateerd dat ze nu en in de toekomst belangrijk (zullen) zijn, zijn vetgedrukt weergegeven.

\section{Tabel 4.2}

Vereist competentieniveau, 2004-2010*

\begin{tabular}{|c|c|c|c|c|}
\hline & $\begin{array}{l}\text { HEO } \\
\text { gem. }\end{array}$ & trend & $\begin{array}{r}\text { HB0-totaal } \\
\text { gem. }\end{array}$ & trend \\
\hline \multicolumn{5}{|l|}{ Kennis van: } \\
\hline eigen vakgebied & 3,7 & n.s. & 3,8 &, 012 \\
\hline andere vakgebieden & 3,3 & n.s. & 3,3 &,- 009 \\
\hline \multicolumn{5}{|l|}{ Vermogen om: } \\
\hline vakkennis in de praktijk toe te passen & 3,7 & n.s. & 3,9 &, 010 \\
\hline informatie-\&communicatietechnologie te gebruiken & 3,8 & n.s. & 3,6 &, 021 \\
\hline in buitenlandse talen te communiceren & 2,9 & n.s. & 2,5 &, 012 \\
\hline informatie te vergaren & 4,0 & n.s. & 3,9 & n.s. \\
\hline problemen en kansen te signaleren & 4,0 & 012 & 4,1 & ,011 \\
\hline verbanden te leggen tussen verschillende zaken & 3,9 &, 016 & 4,0 & ,011 \\
\hline hoofd- van bijzaken te onderscheiden & 3,9 & n.s. & 3,9 & n.s. \\
\hline logisch te redeneren & 4,0 & n.s. & 4,0 & n.s. \\
\hline conform budget, planning of richtlijnen te werken & 3,8 &, 016 & 3,6 & ,014 \\
\hline onder druk goed te functioneren & 4,1 & n.s. & 4,0 & n.s. \\
\hline knopen door te hakken & 3,7 &, 015 & 3,7 &, 012 \\
\hline nieuwe ideeën en oplossingen te bedenken & 3,8 & n.s. & 3,9 & n.s. \\
\hline nieuwe dingen te leren & 3,9 & n.s. & 4,0 & n.s. \\
\hline aan anderen duidelijk te maken wat $\mathrm{u}$ bedoelt & 4,1 & n.s. & 4,2 & ,007 \\
\hline productief met anderen samen te werken & 4,0 &, 009 & 4,0 &, 009 \\
\hline capaciteiten van anderen aan te spreken & 3,6 &, 016 & 3,7 & ,017 \\
\hline zelfstandig de werkzaamheden uit te voeren & 4,2 & n.s. & 4,3 & n.s. \\
\hline \multicolumn{5}{|l|}{ Bereidheid om: } \\
\hline de nek uit te steken & 3,8 & 017 & 3,8 & ,011 \\
\hline eigen en andermans ideeën ter discussie te stellen & 3,7 & 015 & 3,8 &, 010 \\
\hline voor eigen standpunt op te komen & 3,8 & 015 & 3,8 & n.s. \\
\hline begrip te tonen voor andere standpunten & 3,9 & ,015 & 3,9 &, 009 \\
\hline
\end{tabular}

* Gemiddeld antwoord op 5-puntschaal (1'matig'<-> 5'uitmuntend')

Bron: HBO-Monitor 2004-2010

Trends worden alleen vermeld als die op minstens op 5\%-niveau significant zijn.

Data voor HBO-totaal zijn hierbij herwogen.

Het vereiste competentieniveau onder afgestudeerden van het Hoger Economisch Onderwijs is vrij hoog voor de meeste competenties en hetzelfde kan geconcludeerd worden voor het $\mathrm{HBO}$-gemiddelde. Het vereiste niveau is volgens afgestudeerden van het HEO het hoogst wat betreft het vermogen om zelfstandig de werkzaamheden uit te voeren. Ook het vermogen om onder druk goed te functioneren en aan anderen 
duidelijk te maken wat men bedoelt zijn competenties die in belangrijke mate door de werkgever gevraagd worden in hun huidige functie. Ondanks de globalisering en internationaal georiënteerde economie blijkt het vereiste niveau van de communicatie in een buitenlandse taal het laagst van alle 23 onderscheiden competenties. Andere competenties waarbij het vereiste niveau bij de start van de loopbaan relatief laag is zijn de kennis van andere vakgebieden en het kunnen aanspreken van capaciteiten van anderen.

In algemene zin wijkt het vereiste competentieniveau voor HEO'ers niet veel af van het $\mathrm{HBO}$-gemiddelde. Het grootste verschil is terug te zien bij het vermogen om te communiceren in een buitenlandse taal. Bij afgestudeerden van het HEO ligt het vereiste niveau aanzienlijk hoger dan bij andere HBO-ers, wat zeer waarschijnlijk verklaard kan worden door het internationale karakter van deze sector. Andere verschillen zijn dat HEO'ers beter in staat worden geacht om informatie- en communicatietechnologie te gebruiken en conform budget, planning of richtlijnen te werken. Hier staat tegenover dat van HEO'ers, in vergelijking met het $\mathrm{HBO}$-gemiddelde, een minder hoog niveau verwacht wordt wat betreft het kunnen toepassen van vakkennis in de praktijk.

Daarnaast is het interessant om te bekijken welke competenties de laatste jaren belangrijker zijn geworden. Uit tabel 4.2 blijkt eveneens dat voor bijna de helft van de competenties geldt dat het vereiste niveau tussen 2004 en 2010 significant gestegen is. In het bijzonder de bereidheid om de nek uit te durven steken blijkt in toenemende mate van afgestudeerde HEO'ers gevraagd te worden. Andere competenties die de laatste jaren meer en meer op een hoog niveau van HEO'ers gevraagd worden, zijn bijvoorbeeld het moeten kunnen leggen van verbanden tussen verschillende zaken, het werken conform budget, planning en richtlijnen, en het aanspreken van capaciteiten van anderen.

Binnen het $\mathrm{HEO}$ lijkt het niveau van de vereiste competenties minder te veranderen dan in het gehele HBO. Terwijl tussen 2004 en 2010 binnen het HEO Io van de 23 competenties een significante verandering hebben doorgemaakt qua vereist niveau, zijn dit binnen het totale HBO I5 van de 23 competenties. Bij het totale $\mathrm{HBO}$ neemt vooral het belang van ICT-vaardigheden de afgelopen jaren sterk toe. Ook het vereiste competentieniveau voor het aanspreken van andermans capaciteiten zit sterk in de lift. Opvallend genoeg lijken werkgevers met de jaren genoegen te nemen met minder kennis van andere vakgebieden bij de totale groep HBO'ers. Met uitzondering van de competentie: bereidheid om voor het eigen standpunt op te komen, nemen alle competenties met een significante trend bij het HEO eveneens significant toe voor het totale $\mathrm{HBO}$. Bij de vergelijking van de trends voor afzonderlijke competenties tussen het $\mathrm{HEO}$ en het totale $\mathrm{HBO}$ springen enkele specifieke competenties eruit. Zo neemt het vereiste niveau van de bereidheid om de nek uit te durven steken bij het HEO relatief sterk toe ten opzichte van het totale HBO. Hetzelfde kan geconcludeerd worden voor het begrip tonen voor andere standpunten, eigen en andermans ideeën 
ter discussie durven stellen, en verband leggen tussen verschillende zaken. Van al deze competenties neemt het vereiste niveau relatief sterk toe voor HEO-afgestudeerden.

Wanneer we deze trends vergelijken met de verwachte ontwikkelingen die in tabel 4.I werden samengevat, zien we een gedeeltelijke bevestiging dat de ontwikkelingen in het werkdomein van HEO'ers worden weerspiegeld in de competenties waarover ze dienen te beschikken. Zoals werd verwacht vanuit het oogpunt van de toenemende aandacht voor professionalisering en wet- en regelgeving, de toenemende behoefte aan zekerheid en integriteit en het afgenomen consumentenvertrouwen is het conform budget, planning of richtlijnen kunnen werken belangrijker geworden. Ook het vermogen om problemen en kansen te kunnen signaleren wordt op een hoger niveau dan voorheen vereist, zoals we zouden verwachten op basis van de toegenomen behoefte aan zekerheid en ook creativiteit, het groot aantal zzp'ers en startende ondernemers, en de toegenomen concurrentie. Zoals verwacht wordt de toegenomen behoefte aan creativiteit ook vertaald in een grotere nadruk op het vermogen om verbanden te kunnen leggen tussen verschillende zaken. Het is ook veel belangrijker geworden dat men bereid is om de eigen nek uit te steken, ideeën ter discussie te stellen, voor het eigen standpunt op te komen en begrip te tonen voor andere standpunten. Dit is in lijn met de verwachtingen op basis van het toenemende belang van integriteit, de toegenomen concurrentie, en het groter aantal zzp'ers en startende ondernemers. Ook de typische ondernemerscompetentie het vermogen om knopen door te hakken wordt zoals verwacht belangrijker. Er is echter geen indicatie dat het belangrijker wordt om onder druk te kunnen functioneren, nieuwe ideeën en oplossingen te kunnen bedenken of zelfstandig de werkzaamheden uit te kunnen voeren. Daar staat tegenover dat twee competenties belangrijker worden, waar vooraf echter geen ontwikkeling werd verwacht. Het gaat om typische sociale competenties: het vermogen om productief met anderen te kunnen samenwerken en het vermogen om de capaciteiten van anderen aan te kunnen spreken. Hoewel deze trends niet eenduidig zijn af te leiden uit bepaalde ontwikkelingen in het werkdomein van HEO'ers, ligt het voor de hand dat het goed om kunnen gaan met collega's van pas kan komen in de snel veranderende wereld waarin de afgestudeerden terecht komen.

\subsection{Competentietekorten}

Het is de vraag hoe het onderwijs op het veranderde belang van competenties heeft gereageerd. Tabel 4.3 toont de competentietekorten zoals deze ervaren worden door afgestudeerden die in hun kerndomein werkzaam zijn. Wederom zijn de competenties die nu en in de toekomst belangrijk (zullen) zijn vetgedrukt weergegeven. De resultaten worden vergeleken tussen het $\mathrm{HEO}$ en het totale $\mathrm{HBO}$. Omdat in de $\mathrm{HBO}-$ Monitor zowel het vereiste competentieniveau als het eigen competentieniveau op eenzelfde 5-puntschaal (die varieert van I 'matig' tot 5 'uitmuntend') is gemeten, geeft de verschilscore voor iedere competentie een indicatie van een eventueel tekort of overschot. Van een competentietekort is sprake wanneer het vereiste niveau hoger 
is dan het eigen niveau. Het is belangrijk op te merken dat een tekort niet noodzakelijkerwijs negatief hoeft te zijn. Wanneer er namelijk sprake is van een klein tekort wordt dit vaak ervaren als een uitdaging om dit punt te verbeteren. Wanneer afgestudeerden met betrekking tot een bepaalde competentie het gevoel hebben dat zij al een bepaald niveau bereikt hebben, zouden zij wel eens gemakzuchtig kunnen worden en geen noodzaak zien om zich te blijven ontwikkelen op dat punt. Wel kan er een signaalfunctie van deze tekorten uitgaan. Net als bij het vereiste niveau wordt tevens de trend in tekorten, m.a.w. de gemiddelde jaarlijkse toe- of afname weergegeven. De trend wordt berekend op dezelfde wijze als bij het vereist competentieniveau (tabel 4.2) en wordt alleen weergegeven wanneer deze statistisch significant is.

Afgestudeerden van het $\mathrm{HEO}$ ervaren het grootste competentietekort als het gaat om het aan anderen duidelijk maken wat men bedoelt. Ruim een derde $(34,7 \%)$ van de afgestudeerde HEO'ers die werkzaam is in het kerndomein ervaart een tekort bij het vergelijken van het eigen niveau met het niveau dat voor de functie vereist is. Ook schiet naar eigen zeggen de kennis van het eigen vakgebied vaak tekort en vindt eveneens een groot deel dat het eigen niveau van de competentie 'problemen en kansen signaleren' zich onder het vereiste niveau bevindt. Verder ervaren bijna 3 op de Io afgestudeerden van het HEO een competentietekort met betrekking tot hoofd- en bijzaken onderscheiden, conform budget, planning of richtlijnen werken, en knopen doorhakken. Over het niveau van competenties als nieuwe dingen leren en op productieve wijze met anderen samenwerken zijn HEO-afgestudeerden een stuk tevredener. Hier ervaart 'slechts' $15 \%$ een tekort.

In algemene zin kan geconcludeerd worden dat het $\mathrm{HEO}$ qua ervaren competentietekorten niet zo gek veel afwijkt van het $\mathrm{HBO}$-gemiddelde. De grootste verschillen bestaan er tussen het $\mathrm{HEO}$ en het totale $\mathrm{HBO}$ als het gaat om de tekorten over de kennis van het eigen vakgebied en het vermogen om vakkennis in de praktijk toe te passen. In beide gevallen ervaart een kleiner deel van de HEO'ers een tekort dan andere studiegenoten van het HBO. Andere competenties waar HEO'ers relatief minder tekorten ervaren zijn capaciteiten van anderen aanspreken en voor het eigen standpunt opkomen. Hier tegenover staan verschillende competenties waar HEO'ers in vergelijking met het $\mathrm{HBO}$-gemiddelde juist relatief vaak tekorten ervaren. Dit verschil is het grootst bij het communiceren in een buitenlandse taal. Andere competenties waar afgestudeerden van het $\mathrm{HEO}$ een groter tekort ervaren dan andere studiegenoten van het $\mathrm{HBO}$ zijn bijvoorbeeld conform budget, planning of richtlijnen werken, informatie vergaren en begrip tonen voor andere standpunten. 
Tabel 4.3

Ervaren tekort met betrekking tot competenties* (\%)

\begin{tabular}{|c|c|c|c|c|}
\hline & \multicolumn{2}{|c|}{ HEO } & \multicolumn{2}{|c|}{ HBO-totaal } \\
\hline & gem. & trend & gem. & trend \\
\hline \multicolumn{5}{|l|}{ Kennis van: } \\
\hline eigen vakgebied & 32,7 & n.s. & 36,5 & ,492 \\
\hline andere vakgebieden & 26,2 & n.s. & 25,8 & n.s. \\
\hline \multicolumn{5}{|l|}{ Vermogen om: } \\
\hline vakkennis in de praktijk toe te passen & 24,8 & n.s. & 28,6 & n.s. \\
\hline informatie-\&communicatietechnologie te gebruiken & 17,5 & ,871 & 15,9 & ,663 \\
\hline in buitenlandse talen te communiceren & 17,3 & n.s. & 14,3 &, 510 \\
\hline informatie te vergaren & 19,7 &, 435 & 17,6 &, 505 \\
\hline problemen en kansen te signaleren & 32,1 &, 539 & 33,2 &, 690 \\
\hline verbanden te leggen tussen verschillende zaken & 27,1 & 821 & 27,3 &, 662 \\
\hline hoofd- van bijzaken te onderscheiden & 29,3 & n.s. & 27,5 & n.s. \\
\hline logisch te redeneren & 18,6 & ,618 & 18,3 &, 531 \\
\hline conform budget, planning of richtlijnen te werken & 29,8 & ,607 & 27,3 &, 490 \\
\hline onder druk goed te functioneren & 27,9 & n.s. & 28,6 & n.s. \\
\hline knopen door te hakken & 29,1 & ,896 & 29,1 &, 733 \\
\hline nieuwe ideeën en oplossingen te bedenken & 27,9 & ,742 & 28,9 & ,463 \\
\hline nieuwe dingen te leren & 15,1 & ,713 & 15,3 &, 634 \\
\hline aan anderen duidelijk te maken wat u bedoelt & 34,7 & ,678 & 33,3 & ,603 \\
\hline productief met anderen samen te werken & 15,9 & ,757 & 17,4 &, 664 \\
\hline capaciteiten van anderen aan te spreken & 25,5 & 960 & 28,3 &, 535 \\
\hline zelfstandig de werkzaamheden uit te voeren & 20,4 &, 838 & 21,1 & ,615 \\
\hline \multicolumn{5}{|l|}{ Bereidheid om: } \\
\hline de nek uit te steken & 17,1 & ,815 & 17,2 & ,407 \\
\hline eigen en andermans ideeën ter discussie te stellen & 22,2 & 1,145 & 24,1 & ,702 \\
\hline voor eigen standpunt op te komen & 23,8 & ,833 & 26,5 & ,690 \\
\hline begrip te tonen voor andere standpunten & 18,0 & ,677 & 15,9 &, 442 \\
\hline
\end{tabular}

$\mathrm{Na}$ de competentietekorten van HEO'ers vergeleken te hebben met de totale groep HBO'ers, rest nog de vraag welke van deze tekorten groter worden in de tijd. In het Hoger Economisch Onderwijs zijn de meeste competentietekorten de afgelopen jaren groter geworden. Uit tabel 4.3 blijkt namelijk dat er sprake is van een stijgende trend voor 17 van de 23 onderscheiden competenties. Dit betekent dat afgestudeerden van het HEO die werkzaam zijn in het kerndomein tussen 2004 en 2010 in toenemende mate een tekort ervaren tussen hun eigen niveau en het voor de functie vereiste niveau. Met name het tekort wat betreft het ter discussie stellen van eigen en andermans ideeën stijgt relatief sterk in deze periode. Andere competentietekorten die groter zijn 
geworden voor HEO'ers zijn vooral capaciteiten van anderen aanspreken, knopen doorhakken, gebruik maken van ICT, de werkzaamheden zelfstandig uitvoeren, voor het eigen standpunt opkomen, verbanden leggen tussen zaken en bereid zijn om de nek uit te steken. Hoewel het competentietekort voor de totale groep HBO'ers in de afgelopen periode nog vaker toegenomen is (bij 19 van de 23 onderscheiden competenties) dan het geval was voor HEO'ers, is het opvallend dat deze tekorten bij de meeste competenties minder snel oplopen voor de totale groep HBO'ers. Dit blijkt uit de kleinere coëfficiënten die de trend weergeven. De tekorten die het snelst oplopen bij het totale $\mathrm{HBO}$ zijn knopen doorhakken, eigen en andermans ideeën ter discussie stellen, voor het eigen standpunt opkomen, en problemen en kansen signaleren.

De tekorten die jaarlijks het meest oplopen bij afgestudeerden van het HEO ten opzichte van de hele groep HBO-afgestudeerden zijn achtereenvolgens de bereidheid om eigen en andermans ideeën ter discussie te stellen, capaciteiten van anderen aan te spreken, en de nek uit te steken. Hoewel de competentietekorten van HEO-afgestudeerden jaarlijks toenemen voor informatie vergaren en problemen en kansen signaleren, zijn dit de competenties waar het HEO het jaarlijks relatief beter doet dan het $\mathrm{HBO}$-gemiddelde. 


\section{Conclusie}

Economische HBO-opleidingen zijn de laatste jaren erg populair, het Hoger Economisch Onderwijs is al jaren veruit de grootste van de 7 onderscheiden $\mathrm{HBO}$-sectoren. Op de meeste arbeidsmarktindicatoren scoren de economische opleidingen echter iets minder goed dan het $\mathrm{HBO}$-gemiddelde. Afgestudeerden van het HEO lijken bovendien meer last te hebben van laagconjunctuur in de zin dat in die periodes de werkloosheid sterker toeneemt dan gemiddeld, en door verdringingseffecten de afgestudeerden vaker dan gemiddeld buiten het kerndomein werk moeten zoeken wat waarschijnlijk resulteert in lagere bruto uurlonen en spijt achteraf van de gevolgde opleiding. Aan de andere kant lijken de HEO-afgestudeerden bij sommige arbeidsmarktindicatoren ook meer dan gemiddeld te profiteren van economisch betere tijden. Dit geldt bijvoorbeeld voor het reële bruto uurloon en de ervaren aansluiting tussen opleiding en werk.

De toekomstige arbeidsmarktperspectieven voor afgestudeerden van het $\mathrm{HEO}$ zijn (behalve voor het opleidingstype 'accountancy en bedrijfseconomie') matig tot slecht, terwijl die voor de gemiddelde HBO'er juist goed is. Dit komt doordat de arbeidsmarktinstroom van HEO'ers gemiddeld is, terwijl de werkgelegenheidsgroei en de vervangingsvraag lager dan gemiddeld zijn. Afgestudeerden met een opleiding $\mathrm{HBO}$ bedrijfskunde hebben vergeleken met afgestudeerden van andere HEO opleidingen de meeste uitwijkmogelijkheden naar andere beroepen. HBO accountancy en bedrijfseconomie en HBO commerciële economie blijven relatief smal qua uitwijkmogelijkheden. De substitutiemogelijkheden zijn voor de meeste beroepsgroepen in de economische sector vrij groot.

Op basis van algemene en sectorspecifieke trends zijn i3 competenties geformuleerd die de afgelopen jaren belangrijker zijn geworden worden voor HEO-afgestudeerden. Van deze competenties waren er 8 waarvan het vereiste niveau de afgelopen jaren inderdaad significant is gestegen. Deze competenties zijn:

- Vermogen om problemen en kansen te signaleren

- Vermogen om verbanden te leggen tussen verschillende zaken

- Vermogen om conform budget, planning of richtlijnen te werken

- Vermogen om knopen door te hakken

- Bereidheid om uw nek uit te steken

- Bereidheid om ideeën van uzelf en anderen ter discussie te stellen 
- Bereidheid om op te komen voor uw eigen standpunt

- Bereidheid om begrip te tonen voor andere standpunten

Daarnaast zijn er nog twee competenties belangrijker worden, waar vooraf geen ontwikkeling werd verwacht, te weten: het vermogen om productief met anderen samen te werken en het vermogen om capaciteiten van anderen aan te spreken.

Ervaren competentietekorten geven aan waar hogescholen in de toekomst meer aandacht aan zouden kunnen besteden bij de inhoud van het economische onderwijs. De analyses wijzen uit dat zo'n I6 tot $32 \%$ van de afgestudeerde HEO'ers competentietekorten ervaart bij de bovenstaande Io belangrijker wordende competenties. Van de Io belangrijker wordende competenties wordt van de competentie 'problemen en kansen signaleren' het vaakst door HEO-afgestudeerden aangegeven dat ze een tekort ervaren $(32, \mathrm{I} \%$ ervaart een tekort bij deze competentie). Ook relatief veel HEO'ers geven aan dat ze een tekort ervaren op de belangrijke competenties 'conform budget, planning of richtlijnen werken' $(29,8 \%)$ en 'het vermogen om knopen door te hakken' $(29, \mathrm{I} \%)$. 


\section{Literatuur}

ABN Amro (2011), Visie op zakelijke dienstverlening, mei 2011.

Berenschot (2011), Zakelijke dienstverlening, Het hart van de kenniseconomie.

HBO-raad (2010), Branchejaarverslag hbo 2009, Den Haag.

HBO-raad (2012), Inschrijvingen: absolute aantallen.

http://cijfers.hbo-raad.nl/QvAJAXZfc/opendoc.htm?document=2_Inschrijvingen. qvw\&host=Local\&anonymous=true, 29-08-2012

Ministerie van Onderwijs, Cultuur en Wetenschap (2011), Hoofdlijnenakkoord OCW - HBOraad, Den Haag: OCW.

Nederlandse Mededingingsautoriteit (2010), Visiedocument toekomst financiële landschap, Over concurrentie in de financiële sector na de crisis, Den Haag.

Rabobank (2011), Cijfers \& Trends, Branche-informatie: dienstverlening, 35e jaargang, maart 2011.

ROA (2011), De arbeidsmarkt naar opleiding en beroep tot 2016, ROA-R-2011/8, Maastricht University. 



\section{Bijlage: Kernindicatoren voor HEO Bachelor-opleidingen}

Tabel B1

Vijf kernindicatoren voor HEO Bachelor-opleidingen, 2006-2010

\begin{tabular}{|c|c|c|c|c|c|c|}
\hline HEO Bachelor-opleiding & Werkloosheid & $\begin{array}{r}\text { Werkzaam in } \\
\text { kerndomein } \\
\%\end{array}$ & $\begin{array}{r}\text { gem. } \\
\text { Bruto } \\
\text { uurloon } \\
€\end{array}$ & $\begin{array}{r}\text { Spijt } \\
\text { opleiding } \\
\%\end{array}$ & $\begin{array}{r}\text { Tevreden } \\
\text { met } \\
\text { functie } \\
\%\end{array}$ & $n$ \\
\hline Accountancy & 1,3 & 86,8 & 14,11 & 12,9 & 80,9 & 857 \\
\hline Bedrijfseconomie & 3,3 & 79,6 & 14,01 & 19,1 & 73,3 & 2020 \\
\hline Bedrijfskunde Groene sector & 1,4 & 56,9 & 14,21 & 30,1 & 54,4 & 107 \\
\hline Bedrijfskundige Informatica & 3,1 & 78,6 & 15,26 & 14,9 & 71,4 & 894 \\
\hline $\begin{array}{l}\text { Bestuurskunde/ } \\
\text { Overheidsmanagement }\end{array}$ & 5,5 & 50,0 & 15,22 & 29,6 & 46,5 & 234 \\
\hline Commerciële Economie & 5,2 & 60,9 & 13,79 & 27,0 & 62,4 & 3440 \\
\hline Communicatie & 8,6 & 60,4 & 13,50 & 30,1 & 58,2 & 2196 \\
\hline Communicatiesystemen & 5,1 & 62,9 & 14,25 & 39,2 & 65,3 & 310 \\
\hline Economisch-linguïstisch & 11,8 & 53,4 & 13,07 & 29,5 & 71,6 & 103 \\
\hline Facility Management & 5,1 & 54,6 & 13,16 & 31,0 & 57,7 & 1412 \\
\hline Financial Services Management & 2,2 & 61,8 & 15,56 & 25,3 & 63,8 & 240 \\
\hline Fiscale Economie & 1,5 & 79,1 & 14,32 & 21,2 & 71,4 & 189 \\
\hline Hoger Hotelonderwijs & 5,5 & 54,2 & 12,61 & 15,4 & 62,6 & 1351 \\
\hline $\begin{array}{l}\text { Hoger Toeristisch en Recreatief } \\
\text { Onderwijs }\end{array}$ & 6,3 & 33,4 & 11,10 & 39,0 & 50,9 & 1237 \\
\hline $\begin{array}{l}\text { Hogere Europese Beroepen } \\
\text { Opleiding }\end{array}$ & 11,5 & 41,2 & 13,49 & 36,9 & 50,1 & 410 \\
\hline $\begin{array}{l}\text { Informatiedienstverlening en } \\
\text {-management }\end{array}$ & 3,6 & 59,3 & 13,62 & 27,2 & 69,0 & 100 \\
\hline Integrale Veiligheid & 5,7 & 43,4 & 13,90 & 37,8 & 64,7 & 145 \\
\hline Integrale Veiligheidskunde & 6,5 & 51,2 & 14,62 & 30,6 & 58,8 & 236 \\
\hline Internationaal Management & $x$ & $x$ & $x$ & $x$ & $x$ & 11 \\
\hline $\begin{array}{l}\text { International Business and } \\
\text { Languages }\end{array}$ & 8,0 & 56,7 & 12,88 & 24,2 & 57,6 & 588 \\
\hline $\begin{array}{l}\text { International Business and } \\
\text { Management Studies }\end{array}$ & 13,6 & 65,6 & 14,96 & 22,0 & 59,9 & 748 \\
\hline $\begin{array}{l}\text { International Financial } \\
\text { Management }\end{array}$ & $x$ & $x$ & $x$ & $x$ & $x$ & 6 \\
\hline
\end{tabular}




\begin{tabular}{|c|c|c|c|c|c|c|}
\hline HEO Bachelor-opleiding & Werkloosheid & $\begin{array}{r}\text { Werkzaam in } \\
\text { kerndomein } \\
\%\end{array}$ & $\begin{array}{r}\text { gem. } \\
\text { Bruto } \\
\text { uurloon } \\
€\end{array}$ & $\begin{array}{r}\text { Spijt } \\
\text { opleiding } \\
\%\end{array}$ & $\begin{array}{r}\text { Tevreden } \\
\text { met } \\
\text { functie } \\
\%\end{array}$ & Aantal \\
\hline Johan Cruijff University & 2,2 & 52,3 & 14,09 & 9,0 & 68,5 & 56 \\
\hline Journalistiek & 9,4 & 68,0 & 13,48 & 28,1 & 62,1 & 779 \\
\hline Logistiek en Economie & 2,9 & 69,3 & 13,69 & 10,9 & 61,6 & 547 \\
\hline Management, Economie en Recht & 4,6 & 56,1 & 13,92 & 39,3 & 61,6 & 2851 \\
\hline $\begin{array}{l}\text { Media en Entertainment } \\
\text { Management }\end{array}$ & 12,2 & 47,6 & 12,38 & 37,3 & 57,5 & 598 \\
\hline Office management & 5,0 & 26,3 & 12,77 & 57,9 & 75,6 & 24 \\
\hline Ondernemerschap & $x$ & $x$ & $x$ & $x$ & $x$ & 6 \\
\hline Oriëntaalse Talen en Communicatie & 9,1 & 30,0 & 12,51 & 10,8 & 48,1 & 46 \\
\hline HBO Personeel en arbeid & $x$ & $x$ & $x$ & $x$ & $x$ & 12 \\
\hline Personeel en Arbeid & 3,9 & 64,7 & 13,70 & 19,3 & 60,3 & 1520 \\
\hline Rechten & 5,1 & 72,7 & 14,25 & 19,0 & 59,3 & 495 \\
\hline Retail Management & $\mathrm{x}$ & $x$ & $\mathrm{x}$ & $x$ & $x$ & 16 \\
\hline $\begin{array}{l}\text { Small Business en Retail } \\
\text { Management }\end{array}$ & 4,7 & 49,0 & 13,71 & 29,4 & 61,3 & 789 \\
\hline Sportmarketing \& Management & 6,4 & 54,2 & 14,69 & 12,8 & 51,0 & 109 \\
\hline Toerisme en recreatie & 11,9 & 36,5 & 10,21 & 30,6 & 41,4 & 71 \\
\hline Trade Management gericht op Azië & 18,8 & 41,2 & 12,67 & 27,3 & 49,1 & 92 \\
\hline Vastgoed en Makelaardij & 5,8 & 70,2 & 14,17 & 28,9 & 67,7 & 361 \\
\hline Vertaalacademie & 10,3 & 62,9 & 15,57 & 24,1 & 58,1 & 47 \\
\hline Vrijetijdsmanagement & 6,0 & 38,6 & 12,17 & 43,8 & 54,0 & 1308 \\
\hline Totaal HEO Bachelor & 5,7 & 59,9 & 13,53 & 27,1 & 61,8 & 26561 \\
\hline Totaal HBO Bachelor & 4,6 & 70,2 & 13,64 & 19,8 & 67,7 & 70409 \\
\hline
\end{tabular}

$X=$ te weinig waarnemingen (in de periode 2006-2010 in totaal minder dan 20 respondenten)

Opleidingen waarvoor in de periode 2006-2010 in een of meerdere jaren geen gegevens beschikbaar waren, zijn gearceerd.

Bron: HBO-Monitor 2006-2010.

Toelichting

- Werkloosheid: Het werkloosheidspercentage heeft betrekking op de werkloze beroepsbevolking: schoolverlaters zonder werk (of met werk van minder dan 12 uur per week) die op zoek zijn naar betaald werk. Daarbij is tevens als voorwaarde gesteld dat de maatschappelijke positie niet scholier of student is.

- $\quad$ Kerndomein: Het percentage dat aangeeft dat het door de werkgever vereiste opleidingsniveau minimaal HBO is en dat de door de werkgever vereiste opleidingsrichting overeenkomt met of verwant is aan de eigen opleidingsrichting.

- Bruto uurloon: Dit betreft het gemiddelde bruto inkomen in de hoofdfunctie. Dit is inclusief toeslagen maar exclusief inkomen uit overwerk. Er is hier niet gecorrigeerd voor verschillen in leeftijd van de schoolverlaters, maar wel voor inflatie.

- Spijt opleiding: Het percentage dat aangeeft achteraf gezien voor een andere opleiding op hetzelfde of ander niveau te hebben willen kiezen.

- $\quad$ Tevredenheid: Hoe tevreden bent u met uw huidige functie ( 1 'zeer ontevreden' tot en met 5 'zeer tevreden'. Vermeld is het percentage van antwoordcategorie 4 en 5 . 